Article

\title{
Surface Canopy Position Determines the Photosystem II Photochemistry in Invasive and Native Prosopis Congeners at Sharjah Desert, UAE
}

\author{
M. Iftikhar Hussain ${ }^{1,2}$ (D), François Mitterand tsombou ${ }^{3,4}$ and Ali El-Keblawy ${ }^{3, *(D)}$ \\ 1 Research Institute of Science and Engineering (RISE), University of Sharjah, Sharjah P.O. Box 27272, UAE; \\ mih786@gmail.com \\ 2 Department of Plant Biology \& Soil Science, Universidad de Vigo, 36310 Vigo, Spain \\ 3 Department of Applied Biology, Faculty of Science, University of Sharjah, Sharjah P.O. Box 27272, UAE; \\ fmitternanatsombou@sharjah.ac.ae \\ 4 Departmento de Biología Vegetal, Universidad de Málaga, P.O. Box 59, 29080 Málaga, Spain \\ * Correspondence: akeblawy@sharjah.ac.ae
}

Received: 14 May 2020; Accepted: 6 July 2020; Published: 8 July 2020

\begin{abstract}
Plants have evolved photoprotective mechanisms in order to counteract the damaging effects of excess light in hyper-arid desert environments. We evaluated the impact of surface canopy positions on the photosynthetic adjustments and chlorophyll fluorescence attributes (photosystem II photochemistry, quantum yield, fluorescence quenching, and photon energy dissipation), leaf biomass and nutrient content of sun-exposed leaves at the south east (SE canopy position) and shaded-leaves at the north west (NW canopy position) in the invasive Prosopis juliflora and native Prosopis cineraria in the extreme environment (hyper-arid desert area, United Arab Emirates (UAE)). The main aim of this research was to study the photoprotection mechanism in invasive and native Prosopis congeners via the safe removal—as thermal energy—of excess solar energy absorbed by the light collecting system, which counteracts the formation of reactive oxygen species. Maximum photosynthetic efficiency $\left(\mathrm{F}_{\mathrm{v}} / \mathrm{F}_{\mathrm{m}}\right)$ from dark-adapted leaves in P. juliflora and P. cineraria was higher on NW than SE canopy position while insignificant difference was observed within the two Prosopis congeners. Greater quantum yield was observed in P. juliflora than P. cineraria on the NW canopy position than SE. With the change of canopy positions from NW to SE, the reduction of the PSII reaction center activity in the leaves of both Prosopis congeners was accelerated. On the SE canopy position, a significant decline in the electron transport rate (ETR) of in the leaves of both Prosopis congeners occurred, which might be due to the blockage of electron transfer from QA to $Q B$ on the PSII acceptor side. On the SE canopy position; Prosopis leaves dissipated excess light energy by increasing non-photochemical quenching (NPQ). However, in P. cineraria, the protective ability of NPQ decreased, which led to the accumulation of excess excitation energy $(1-\mathrm{qP}) / \mathrm{NPQ}$ and the aggravation of photoinhibition. The results also explain the role of different physiological attributes contributing to invasiveness of P. juliflora and to evaluate its liaison between plasticity of these characters and invasiveness.
\end{abstract}

Keywords: chlorophyll $a$ fluorescence; leaf $\mathrm{C}$; leaf $\mathrm{N}$; thermal energy dissipation; $\mathrm{CO}_{2}$ assimilation rate; Prosopis species; photosynthetic efficiency

\section{Introduction}

The plants convert the sunlight into chemical energy during the photosynthetic process and some of the light energy is fixed and converted into chemical energy during the photosynthesis, but still some cannot be fully utilized and might cause potential damage [1-3]. Whenever the light energy can be converted into chemical energy safely, there will be no hazard to plant metabolism. However, if sunlight 
is absorbed but cannot be fully employed, there might be some potential damage to plant physiological apparatus. This situation might be more serious when plant growth is restricted due to extreme environments such as hyper-arid desert conditions; thus, causing intrinsic photosynthetic capacity to drop, where truly massive levels of excess excitation energy are encountered. An incomplete utilization of absorbed sunlight is in fact, quite common, and all plants experience such conditions under full-sun exposure where light energy levels exceed even the highest known photosynthesis rates. This excess absorbed energy has the potential to damage through transfer to the ever-present oxygen, leading to the formation of reactive oxygen species (ROS) that might cause cell damage and leaf destruction and impairment [4]. To escape and avoid the potential damage from excess sunlight, and accumulation of ROS, plants exhibit a series of self-protection mechanisms that includes efficient utilization of sunlight and dissipation of excess energy [5-10]. Apart from this, plants might employ some short- and long-term protection mechanisms that include change in the positioning, function, and stoichiometry of photosystem core components and light-harvesting antennae complex [11,12]. In closed canopy of big trees, south east-facing (SE) leaves, which are exposed to more intense insolation, should be physiologically adapted to such destructive effects of solar radiation; as compared to north west-facing (NW) leaves that receive lower light intensity [13]. Conversely, leaves on shaded NW direction of the canopy should have other morphological and physiological adjustment to cope low intensity of sun light. Some plants might accumulate more nitrogen, proteins, and chlorophyll pigments [14] and more stomata in their leaves for maximum utilization of sunlight [15]. The capability of a plant to capture the solar radiation and use them in an efficient way is very important because following this procedure, plants can avoid photo-damage due to excess light [16,17].

Species of Prosopis occur globally as native or introduced large shrubs and trees in 129 countries, mainly in hot-arid and semi-arid regions [18]. Prosopis juliflora is a fast-growing tree (5-10 $\mathrm{m} \mathrm{height),}$ native to Peru, Central America, and the Caribbean, with long lateral shallow and deep taproot systems that are also able to fix atmospheric nitrogen $[19,20]$. Prosopis juliflora has been introduced intentionally in the United Arab Emirates (UAE) for an afforestation program during the 1970s [21,22]. Several years after its introduction, it invaded most of the eastern emirates of the UAE, where annual average rainfall is higher and groundwater table is shallow [23]. Several characteristics make P. juliflora among the most successful invaders in the world. These include the great reproductive efforts and rapid growth rates [24], deep root systems (>50 $\mathrm{m}$ depth) to tap the groundwater [25], and production of allelochemicals that could reduce seed germination and growth of associated species [26,27]. The adaptation of an introduced tree to a forestation program, in hot-arid environment depends upon its ability to utilize efficiently the available resources (e.g., water and nutrients) and deal with light intensity that might be higher or lower than in its native range [28]. Phenotypic plasticity is crucial for invasive plants to colonize new environments, increasing ecological breadth and potential use of the available resources [29-31]. The invasive species might gain a particular advantage over the native species through its capacity to acclimatize higher intensity of sunlight and dissipate excess light as heat using its photosynthetic plastic features [32,33]. Despite several studies having extensively reported on the impact of temperature, diurnal pattern of variations, vapor pressure deficit on photosynthesis in Prosopis species [34,35], and heat tolerance of shade and sun exposed leaves on photoprotection mechanism in different tropical tree species [36]. However, the relative contribution of dissipation of excess energy to photosynthetic efficiency in leaves exposed to South East (SE) and North West (NW) directions of canopies of the invasive $P$. juliflora and native $P$. cineraria in the hyper-arid climate of the UAE, is unknown. The objective of the present work was to evaluate the chlorophyll fluorescence attributes at two canopy positions in native and exotic invasive Prosopis congeners. This could help in understanding the responses of leaves towards different light intensities and how the native and exotic Prosopis deal with excess energy absorbed by chlorophyll through safely dissipation as heat rather than being transferred to oxygen and resulting in ROS production. To this aim, the following hypothesis were tested: (1) Does leaves in the SE facing direction (exposed to more intense light and heat) differ in photosynthetic traits from leaves exposed to the cooler and shaded NW direction? 
(2) Does the thermal energy dissipation is a safe exit in Prosopis congeners to avoid oxidative damage and provides the photo-protection to the plants? (3) Does the increase or decrease in the electron transport rate (ETR) and non-photochemical quenching (NPQ) play a significant role in protection of photosystem II photochemistry? (4) Are the native P. cineraria and invasive P. juliflora having different photoprotection mechanisms under hyper-arid desert environment? (5) Does the nutrient homeostasis in different canopy directions contribute better in photosynthetic process in the native Prosopis than invasive?

\section{Materials and Methods}

\subsection{Study Site, Experimental Setup and Sampling}

The study was carried out during early summer season in May 2018 at Muntaza desert area, in Sharjah Emirates, United Arab Emirates (Figure 1; lat-25.499005 N and long-55.686018 E). In this area, there is a natural established forest, where both P. juliflora and P. cineraria coexisted. The Muntaza desert area has a tropical hyper-arid bioclimate [37]. Prosopis cineraria is a native tree in the UAE and Arabian Gulf deserts while Prosopis juliflora is an exotic invasive tree, adapted to the high thermal oscillation and solar radiation of the desert [37]. The climate at the study area is hyper-arid with an average of 9 months hot, dry weather with high temperature and 1-2 months occasional rainfall. The total annual precipitation in the study year was $48.1 \mathrm{~mm}$, which is considered below the long-term average. The mean annual temperature was $26.99{ }^{\circ} \mathrm{C}$ with mean daily evapotranspiration being $5.96 \mathrm{~mm} /$ day; it was $8.17 \mathrm{~mm} /$ day during the study month (May 2018). A detailed climatic attributes during the study period are depicted in Table 1. The complete meteorological data of the experimental site was obtained from online portal of IWMI (International Water Management Institute) (http://wcatlas.iwmi.org/Default.asp).

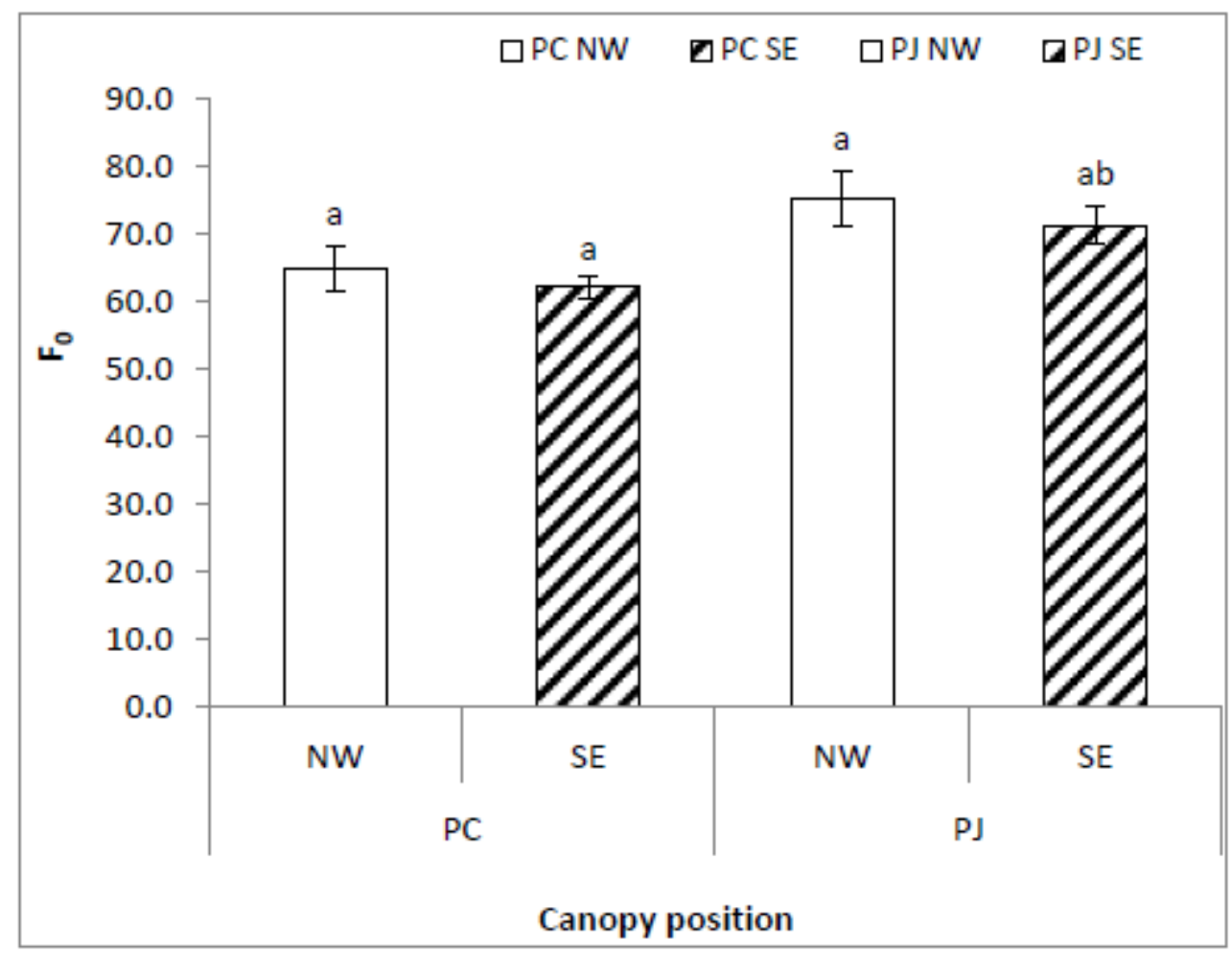

(A)

Figure 1. Cont. 


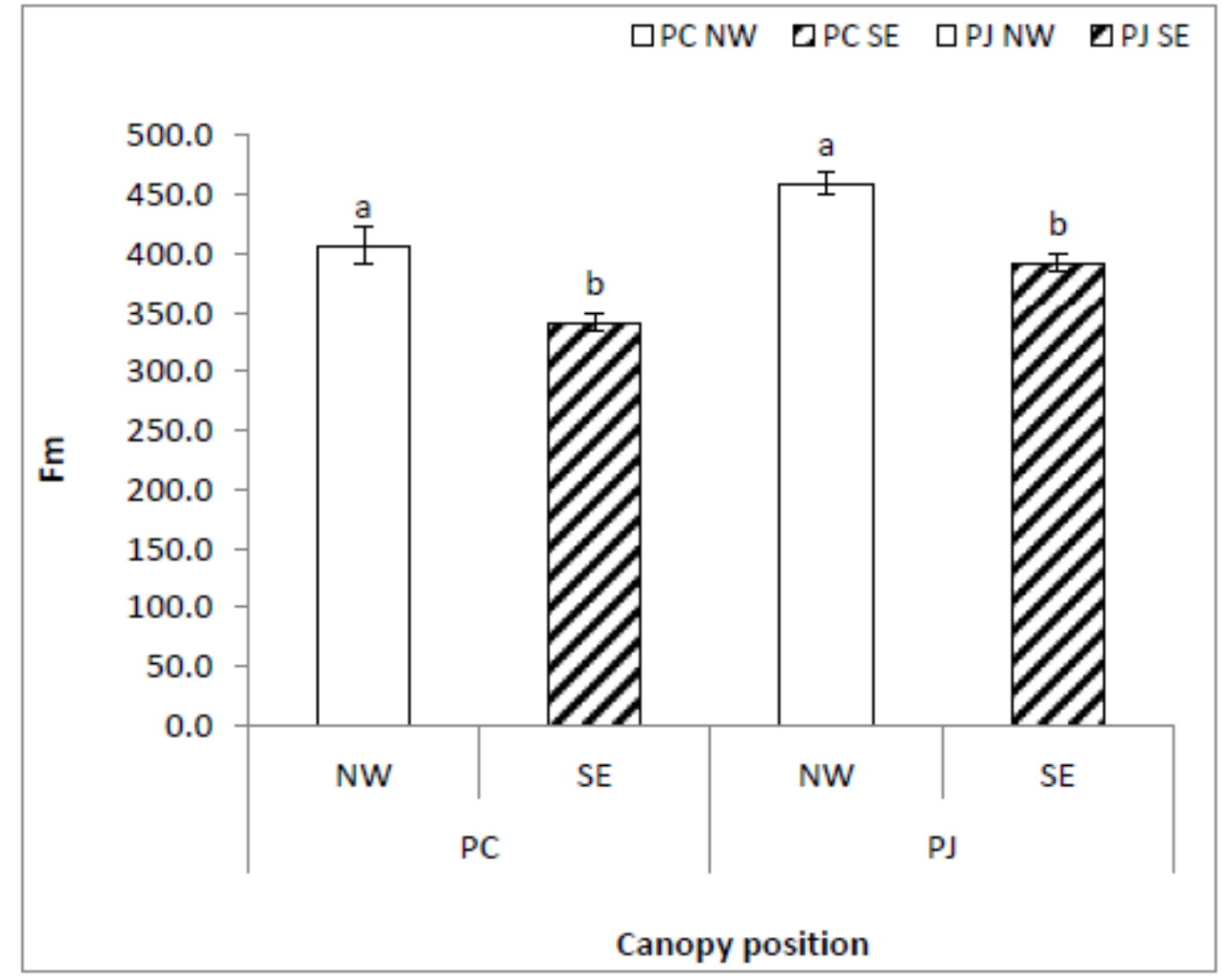

(B)

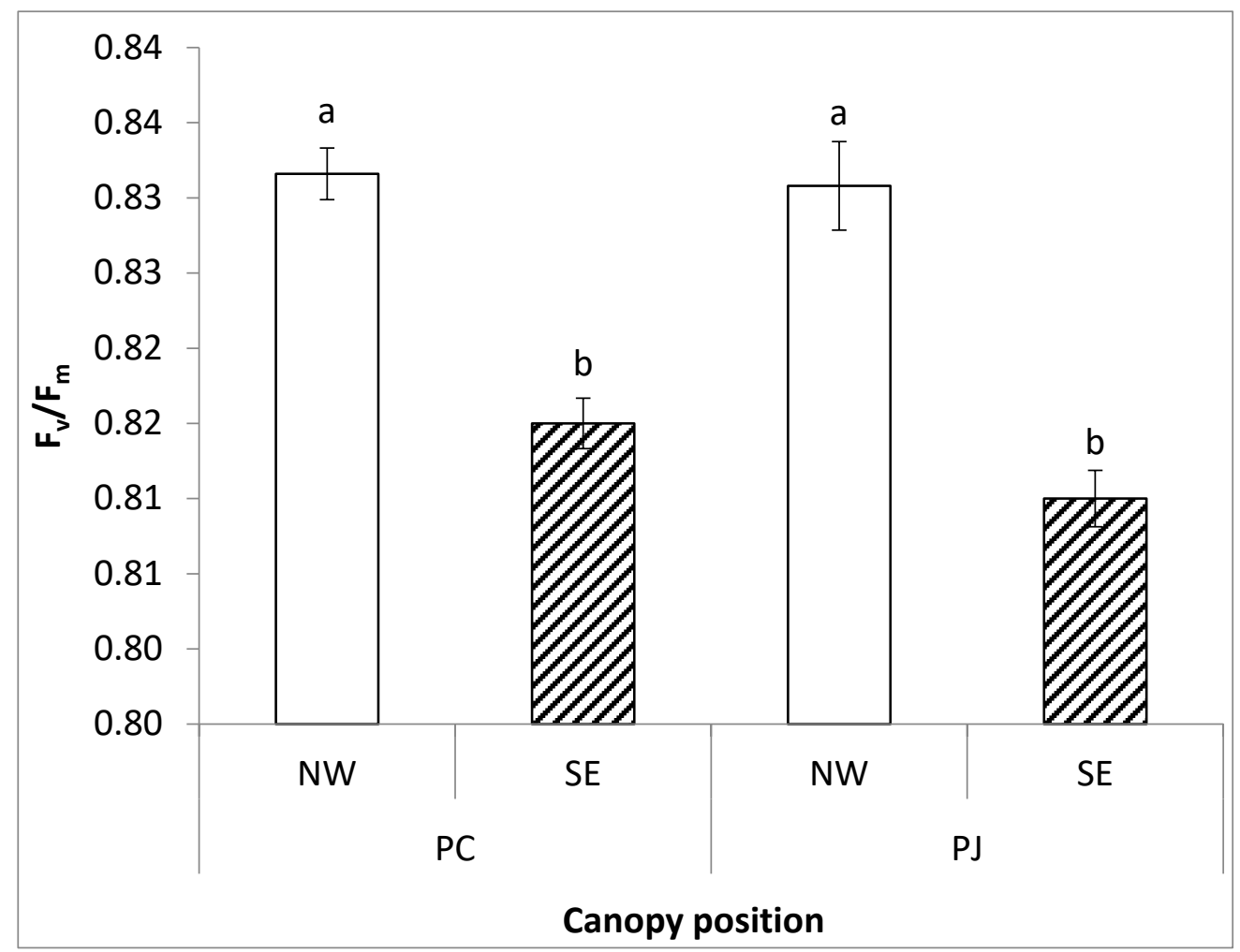

(C)

Figure 1. Cont. 


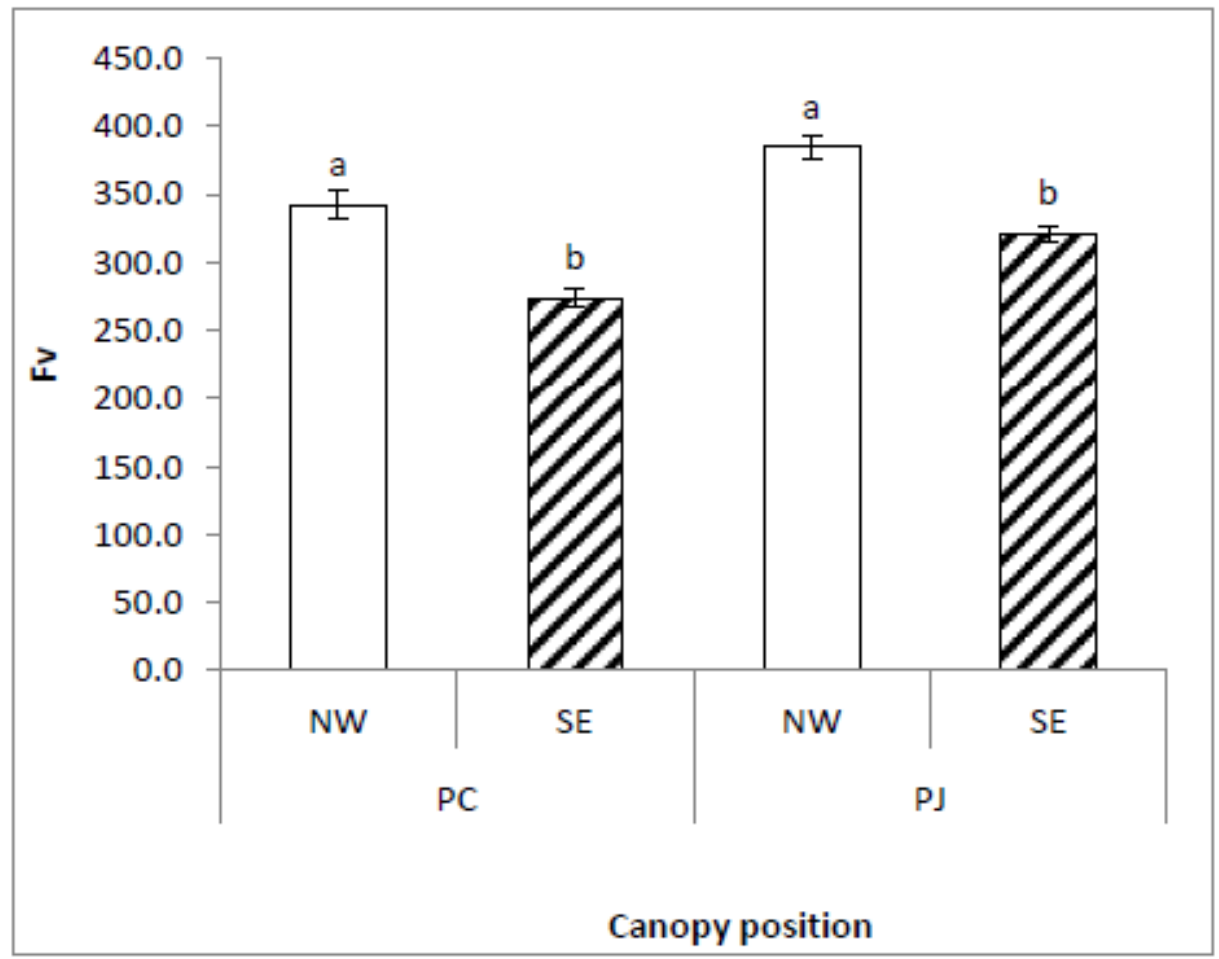

(D)

Figure 1. Changes in chlorophyll fluorescence parameters (A) $F_{0}$, (B) $F_{m},(C) F_{v} / F_{m}$, and (D) $F_{v}$ in Prosopis juliflora and Prosopis cineraria from two different canopy positions (south east, SE; north west, $\mathrm{NW})$. Each bar in a graph represents the mean $( \pm$ S.E.) of three replicates. Means with the same letters within a species indicate insignificant difference between the two canopy positions at $p>0.05$ according to Duncan Multiple range test.

Table 1. Field site surveyed in this study area was Muntaza Desert, at Sharjah Emirates and climate data (2018) are mean annual of interpolated data obtained from online portal of IWMI (International Water Management Institute) (http://wcatlas.iwmi.org/Default.asp).

\begin{tabular}{ccccccccc}
\hline Sites & MAP $(\mathbf{m m})$ & MAT $\left({ }^{\circ} \mathbf{C}\right)$ & DTR $\left({ }^{\circ} \mathbf{C}\right)$ & RH $(\%)$ & SH $(\%)$ & WR $(\mathbf{m} / \mathbf{s})$ & MAI & PM $(\mathbf{m m} /$ Day) \\
\hline Jan & 5.13 & 18.3 & 11.8 & 68 & 73 & 2.9 & 0.01 & 3 \\
Feb & 17.59 & 19.2 & 11.8 & 67 & 72 & 3.3 & 0.04 & 3.67 \\
Mar & 13.25 & 22.2 & 12.8 & 63 & 68 & 3.5 & 0.02 & 4.83 \\
Apr & 3.28 & 26.5 & 14.7 & 56 & 76 & 3.5 & 0 & 6.64 \\
May & 0.01 & 30.4 & 15.5 & 52 & 82 & 3.6 & 0 & 8.17 \\
Jun & 0 & 32.9 & 15.1 & 56 & 82 & 3.8 & 0 & 8.6 \\
Jul & 0 & 35 & 13.6 & 55 & 77 & 3.6 & 0 & 8.67 \\
Aug & 0 & 34.7 & 12.9 & 57 & 78 & 3.7 & 0 & 8.29 \\
Sep & 0 & 32.2 & 14.6 & 61 & 83 & 3.3 & 0 & 7.01 \\
Oct & 0.03 & 28.5 & 14.6 & 62 & 85 & 2.9 & 0 & 5.46 \\
Nov & 0.56 & 23.9 & 13.8 & 63 & 85 & 2.8 & 0 & 4.1 \\
Dec & 8.3 & 20.1 & 12.2 & 67 & 76 & 2.8 & 0.03 & 3.11 \\
Mean & 4.01 & 26.99 & 13.62 & 60.58 & 78.08 & 3.31 & 0.01 & 5.96 \\
\hline
\end{tabular}

$\mathrm{MAP}$, mean annual precipitation; MAT, mean annual temperature; DTR, daily temperature range; $\mathrm{RH}$, relative humidity; SH, sunshine hours; WR, wind run; MAI, moisture availability index; and PM, Penman-Montieth.

\subsection{Pulse-Modulated Chlorophyll Fluorescence Measurements}

Chlorophyll fluorescence measurements were conducted between 09:00 a.m. and 16:00 p.m. using a pulse-modulated fluorescence monitoring system (FMS-2, Hansatech Instruments Ltd., Norfolk, UK) according to the method described previously [1,9,10,38]. Data was collected from five fully expanded young leaflets from five branches (at the NW and SE canopy position) and 
pooled as one replicate. Three trees per Prosopis species were selected and individual tree was $10 \mathrm{~m}$ away from the other tree. Our observations indicated that the trees were not affected by the shade of any other neighboring trees. Leaves were dark-adapted using Walz leaf clips for $20 \mathrm{~min}$. The minimal fluorescence level in the dark-adapted state $\left(\mathrm{F}_{\mathrm{o}}\right)$ was measured using a modulate pulse (PPFD $<0.05 \mu \mathrm{mol}$ (photon) $\mathrm{m}^{-2} \mathrm{~s}^{-1}$ ) too small to induce significant physiological changes [39]. However, this is difficult to accomplish for those leaves which have already reached the steady state in the light under open field environmental conditions, even when the light energy from the "measuring" beam is kept as low as possible. Maximal fluorescence $\left(\mathrm{F}_{\mathrm{m}}\right)$ was measured after applying a saturating actinic light pulse of $15,000 \mu \mathrm{mol}$ (photon) $\mathrm{m}^{-2} \mathrm{~s}^{-1}$ for $0.7 \mathrm{~s}$ and the value of $\mathrm{F}_{\mathrm{m}}$ was recorded as the highest average of two consecutive points. The chlorophyll fluorescence parameters such as efficiency of photosystem II photochemistry $\left(\mathrm{F}_{\mathrm{v}} / \mathrm{F}_{\mathrm{m}}\right)$, quantum yield $(\Phi P S I I)$, and electron transport rate $(\mathrm{ETR}=0.5 \times 0.85 \times \Phi \mathrm{PSII} \times \mathrm{PFD})$ measurements were conducted. Here, 0.5 is the distribution ratio of light energy between PSII and PSI, 0.85 is the light absorption coefficient of leaves, and PFD is the light intensity $\left(\mu \mathrm{mol} \mathrm{m}{ }^{-2} \mathrm{~s}^{-1}\right)[40,41]$. The other photosynthetic parameters such as quenching $\left(\mathrm{qP}=\left(\mathrm{F}_{\mathrm{m}^{\prime}}-\mathrm{F}_{\mathrm{s}}\right) /\left(\mathrm{F}_{\mathrm{m}^{\prime}}-\mathrm{F}_{\mathrm{o}^{\prime}}\right)\right.$, and non-photochemical fluorescence quenching $\left(\mathrm{NPQ}=\left(\mathrm{F}_{\mathrm{m}}-\mathrm{F}_{\mathrm{m}^{\prime}}\right) / \mathrm{F}_{\mathrm{m}^{\prime}}\right)$ were measured as described previously $[1,38]$. The excess excitation energy of the PSII reaction center was calculated as $(1-\mathrm{qP}) / \mathrm{NPQ}$.

\subsection{Plant Biomass Determination and Elemental Analysis}

All morphological and physiological measurements from each selected tree were made at $~ 1.7-\mathrm{m}$ height, where the environmental conditions were more homogeneous during the day (radiation and wind). Leaf biomass and relative water content (WC) was determined by using the following equation; $\mathrm{WC}(\%)=\frac{(\mathrm{FW}-\mathrm{DW})}{\mathrm{FW}} * 100$ according to procedure described by [42]. To estimate the $\mathrm{C}$ and $\mathrm{N}$ contents, three branches, each 1-m length, were harvested from both SE and NW directions of the two Prosopis species. Leaves were separated from the branches, dried at $70{ }^{\circ} \mathrm{C}$ for a constant weight and then $\mathrm{C}$ and $\mathrm{N}$ contents were assessed using elemental analyzer with a standard protocol [43]. In addition, sub-samples (50 mg) of the leaves were used to measure different elements through $X$-ray fluorescence technique using Horiba's XGT 7200 X-ray analytical microscope (XAM) and procedure as elaborated by [44] and as reported previously [45].

\subsection{Experimental Design and Statistical Analysis}

The experiment was laid out in a Nested Block Design with three replications. Data was analyzed by ANOVA (analysis of variance) using General Linear Model procedure through statistical software, SPSS Version 21.0 (SPSS Inc., Chicago, IL, USA). Significant difference among group means was compared by Duncan Multiple range test $(p<0.05)$. Microsoft Excel was employed to calculate average and standard deviation for growth, biomass, and leaf water contents (WC) attributes.

\section{Results}

\subsection{Effects of Canopy Position (NW and SE) on Photosystem II Photochemistry Traits in P. cineraria and P. juliflora}

The effects of Prosopis species (P. cineraria and P. juliflora) on several chlorophyll fluorescence traits $\left(\mathrm{F}_{\mathrm{o}} ; \mathrm{F}_{\mathrm{m}} ; \mathrm{F}_{\mathrm{v}} ; \mathrm{F}_{\mathrm{s}} ; \mathrm{F}_{\mathrm{m}^{\prime}} ; \mathrm{F}_{\mathrm{o}^{\prime}} ; \mathrm{F}_{\mathrm{v}^{\prime}} ;\right.$ and $\left.\mathrm{F}_{\mathrm{v}^{\prime}} / \mathrm{F}_{\mathrm{m}^{\prime}}\right)$ were significant $(p<0.01 ;$ Table 2$)$. The effects of interaction between Prosopis species (P. cineraria and P. juliflora) and canopy position (SE and NW) on different chlorophyll fluorescence attributes $\left(\mathrm{F}_{\mathrm{o}} ; \mathrm{F}_{\mathrm{m}} ;\right.$ and $\left.\mathrm{F}_{\mathrm{v}} / \mathrm{F}_{\mathrm{m}}\right)$ were significant $(p<0.01)$ and $\mathrm{F}_{\mathrm{o}^{\prime}}$ at $(p<0.05$; Table 2). The $P$. juliflora leaves attained significantly higher values of initial fluorescence $\left(\mathrm{F}_{\mathrm{o}}\right)$, maximum fluorescence $\left(\mathrm{F}_{\mathrm{m}}\right)$, and variable fluorescence $\left(\mathrm{F}_{\mathrm{v}}\right)$, as compared to $P$. cineraria (Figure 1$)$. In dark-adapted leaves of $P$. juliflora, efficiency of photosystem II photochemistry $\left(\mathrm{F}_{\mathrm{v}} / \mathrm{F}_{\mathrm{m}}\right)$ was significantly higher at the NW as compared to the SE canopy position (Figure 1c). Similar results were obtained in P. cineraria, 
where $F_{v} / F_{m}$ was also higher on NW canopy position than SE (Figure 1). Insignificant difference was obtained for $\mathrm{F}_{\mathrm{v}} / \mathrm{F}_{\mathrm{m}}$ between the two Prosopis species.

Table 2. ANOVA (F-values) testing the effects of Prosopis species (P. cineraria and P. juliflora) and canopy position (southeast and northwest) on (a) several chlorophyll fluorescence traits and (b) leaf nutrient concentrations. The numerator and denominator degrees of freedom are 1 and 8 , respectively.

\begin{tabular}{|c|c|c|c|}
\hline \multirow{2}{*}{ Variable } & \multicolumn{3}{|c|}{ Source of Variation } \\
\hline & Species (S) & Directions (D) & $S \times D$ \\
\hline \multicolumn{4}{|c|}{ (a) chlorophyll fluorescence traits } \\
\hline $\mathrm{F}_{\mathrm{O}}$ & $7.627^{*}$ & 0.891 & 0.036 \\
\hline $\mathrm{F}_{\mathrm{m}}$ & $5.396^{*}$ & $8.739^{*}$ & 0.002 \\
\hline $\mathrm{F}_{\mathrm{v}} / \mathrm{F}_{\mathrm{m}}$ & 0 & $17.60^{* *}$ & 0.039 \\
\hline $\mathrm{F}_{\mathrm{V}}$ & $5.90^{*}$ & $10.87^{*}$ & 0 \\
\hline $\mathrm{F}_{\mathrm{S}}$ & $32.68^{* * *}$ & 1.527 & 1.243 \\
\hline $\mathrm{F}_{\mathrm{m}^{\prime}}$ & $22.84^{* *}$ & $37.91^{* * *}$ & 0.275 \\
\hline ФPSII & 0.639 & $29.84^{* *}$ & 0.136 \\
\hline $\mathrm{F}_{\mathrm{O}^{\prime}}$ & $12.3^{* *}$ & 1.368 & 0.001 \\
\hline $\mathrm{F}_{\mathrm{v}^{\prime}}$ & $21.14^{* *}$ & $37.16^{* * *}$ & 0.276 \\
\hline $\mathrm{F}_{\mathrm{v}^{\prime}} / \mathrm{F}_{\mathrm{m}^{\prime}}$ & $7.44^{*}$ & $15.21^{* *}$ & 2.845 \\
\hline $\mathrm{qP}$ & 3.593 & $16.94^{* *}$ & 0.238 \\
\hline NPQ & 0.677 & $6.92^{*}$ & 1.265 \\
\hline $\operatorname{HED}(1-\tilde{q P}) / N P Q$ & $7.48^{*}$ & $7.45^{*}$ & 4.02 \\
\hline \multicolumn{4}{|c|}{ (b) Leaf nutrient concentrations } \\
\hline $\mathrm{Mg}$ & $4.216^{*}$ & $12.66^{* *}$ & 0.40 \\
\hline $\mathrm{P}$ & $462.35^{* * *}$ & $12.52^{* *}$ & 0.10 \\
\hline$S$ & $203.30^{* * *}$ & $45.41^{* * *}$ & 4.47 \\
\hline $\mathrm{Cl}$ & $62.37^{* * *}$ & $45.80^{* * *}$ & $203.21^{* * *}$ \\
\hline $\mathrm{K}$ & $2004.45^{* * *}$ & $71.57^{* * *}$ & $200.58^{* * *}$ \\
\hline $\mathrm{Ca}$ & $734.01^{* * *}$ & $41.29^{* * *}$ & $5.73^{*}$ \\
\hline $\mathrm{Fe}$ & $154.79^{* * *}$ & $107.27^{* * *}$ & $11.08^{*}$ \\
\hline $\mathrm{Zn}$ & $29.49^{* * *}$ & $8.09^{*}$ & $13.33^{* * *}$ \\
\hline
\end{tabular}

The asterisks $\left(^{*}\right)$ indicate significance at $0.05,\left(^{* *}\right)$ at 0.01 and $\left(^{* * *}\right)$ at 0.001 level.

\subsection{Impact of Canopy Position on $F_{v^{\prime}} / F_{m^{\prime}}$ and ETR in Leaves of P. juliflora and P. cineraria}

In light-adapted state, maximum fluorescence $\left(\mathrm{F}_{\mathrm{m}^{\prime}}\right)$, and variable fluorescence $\left(\mathrm{F}_{\mathrm{v}^{\prime}}\right)$ values were greater in the NW canopy positions as compared to SE in both Prosopis species (Figure 2). However, P. juliflora leaves showed higher values of $\mathrm{F}_{\mathrm{m}^{\prime}}$ and $\mathrm{F}_{\mathrm{v}^{\prime}}$ as compared to P. cineraria. Quantum yield of photosynthesis in the light adapted leaves (ФPSII) was greater in both P. juliflora and P. cineraria on the NW canopy position as compared to SE. The photosynthetic efficiency in light adapted leaves $\left(\mathrm{F}_{\mathrm{v}^{\prime}} / \mathrm{F}_{\mathrm{m}^{\prime}}\right)$ was greater in P. juliflora on NW canopy position than SE. Similar results were obtained in $\mathrm{F}_{\mathrm{v}^{\prime}} / \mathrm{F}_{\mathrm{m}^{\prime}}$ values in P. cineraria. The effects of canopy position on ETR of two Prosopis congeners were significant $(p<0.001)$, and there was a very significant interaction between canopy position and two Prosopis congeners (Figure 3). Compared with the P. cineraria, the ETR of P. juliflora decreased to varying degrees under different canopy positions. 


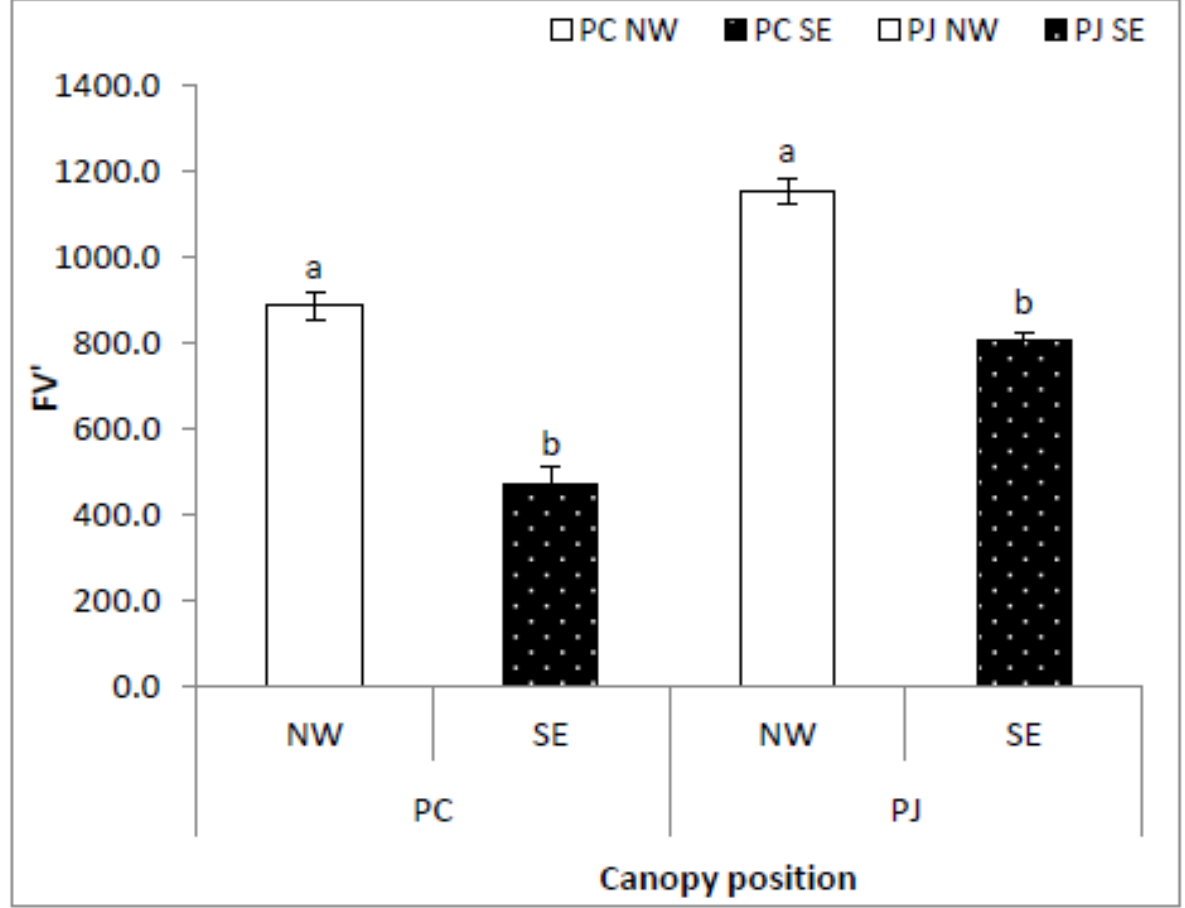

(A)

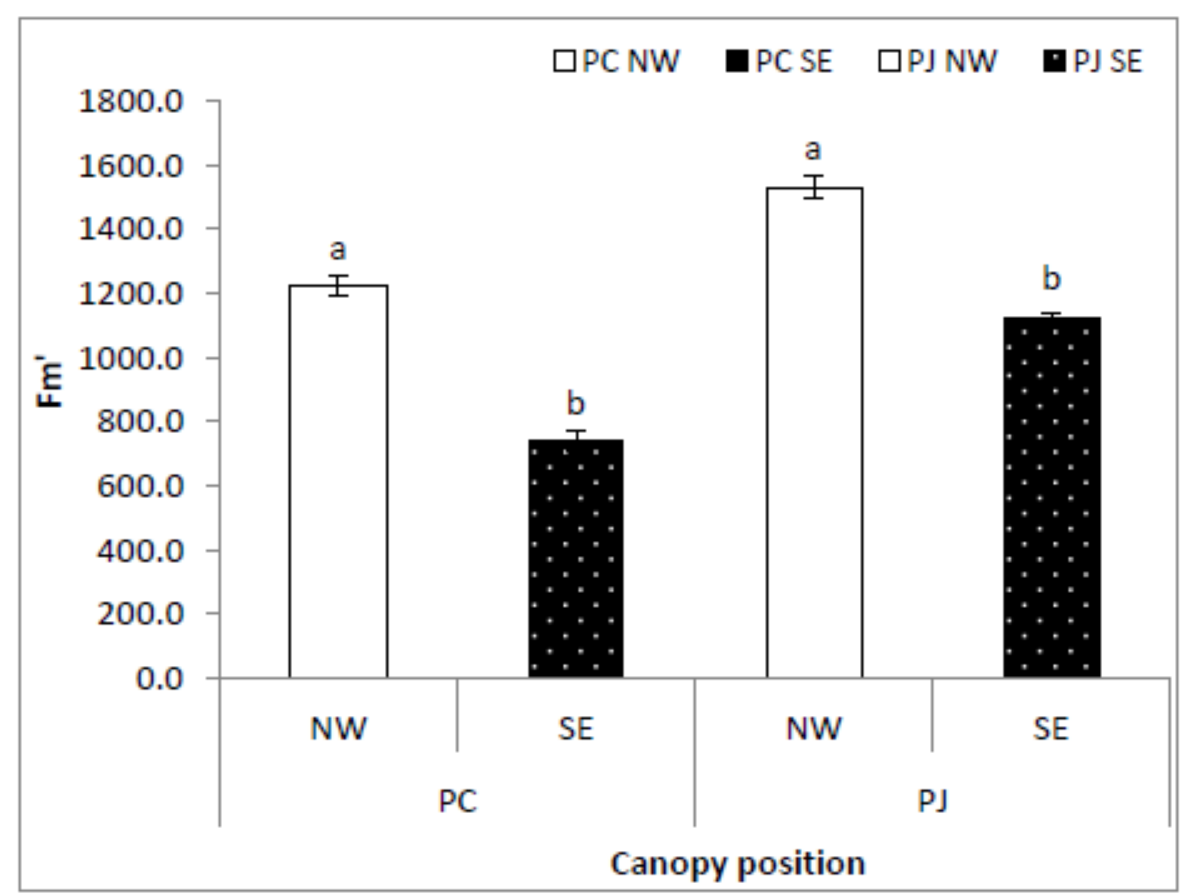

(B)

Figure 2. Cont. 


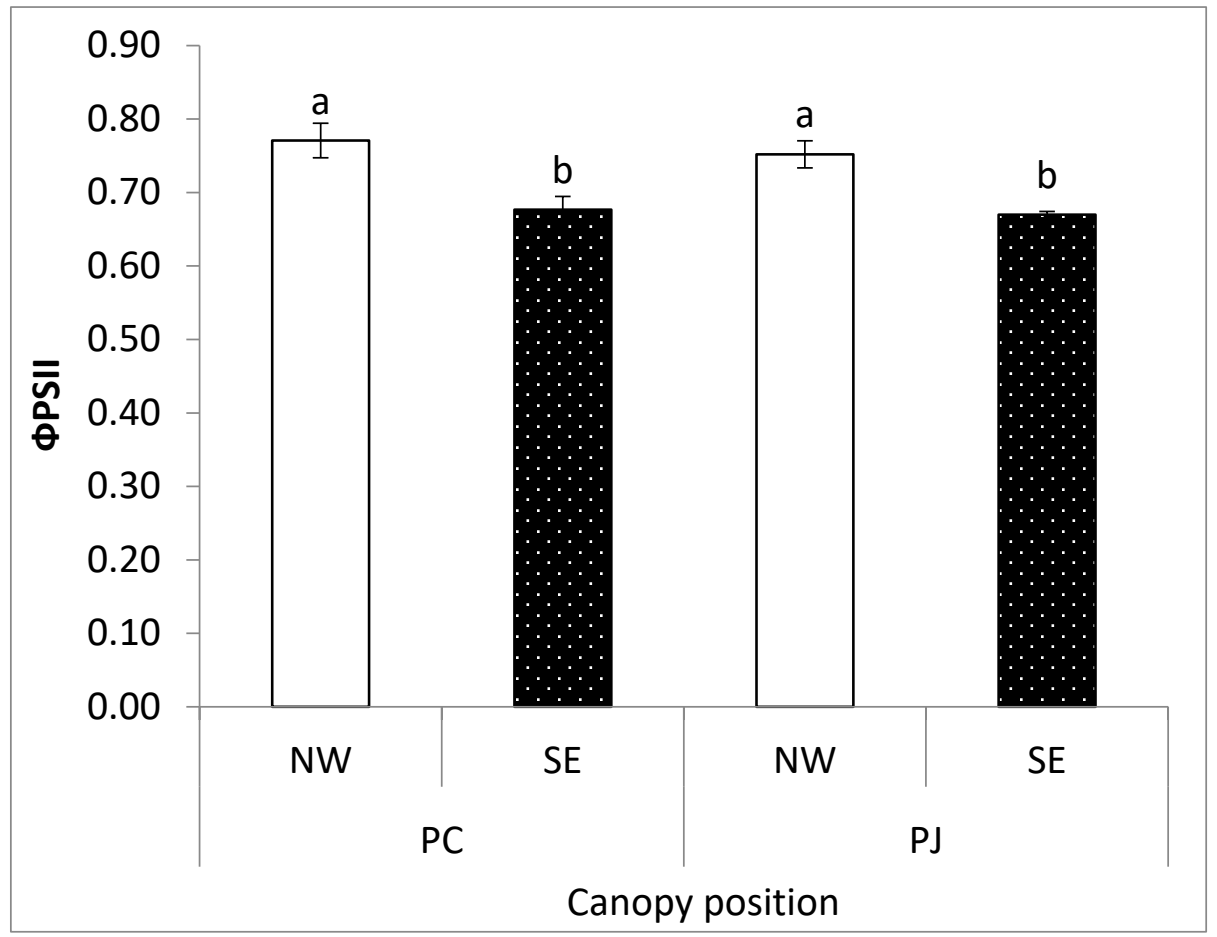

(C)

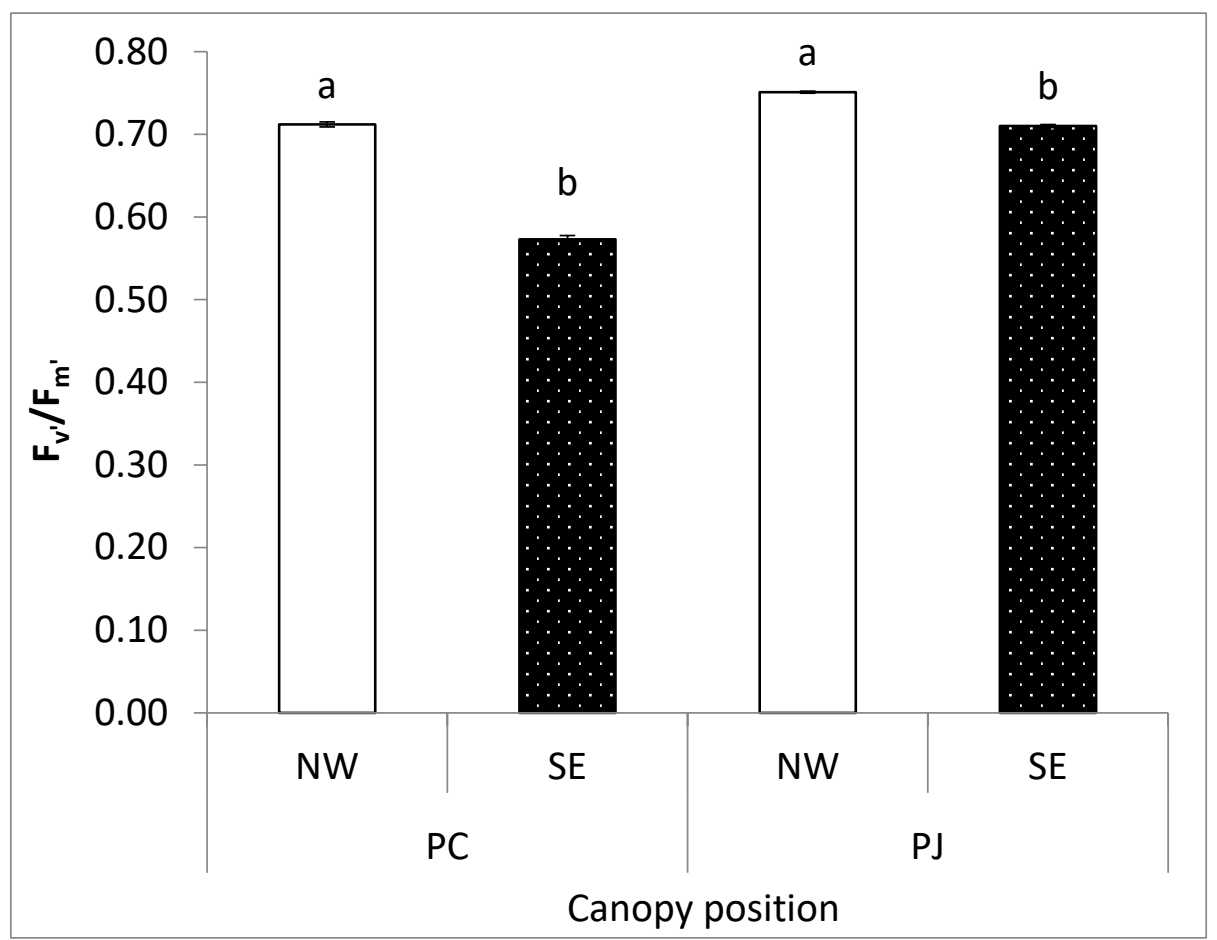

(D)

Figure 2. Changes in chlorophyll fluorescence parameters (A) $\mathrm{F}_{\mathrm{v}^{\prime}},(\mathbf{B}) \mathrm{F}_{\mathrm{m}^{\prime}},(\mathbf{C}) \Phi P S I I$, and (D) $\mathrm{F}_{\mathrm{v}^{\prime}} / \mathrm{F}_{\mathrm{m}^{\prime}}$ in Prosopis juliflora and Prosopis cineraria, respectively, from two different canopy positions (south east, $\mathrm{SE}$; north west, NW). Each bar in a graph represents the mean ( \pm S.E.) of three replicates. Means with the same letters within a species indicate insignificant difference between the two canopy positions at $p>0.05$ according to Duncan Multiple range test. 


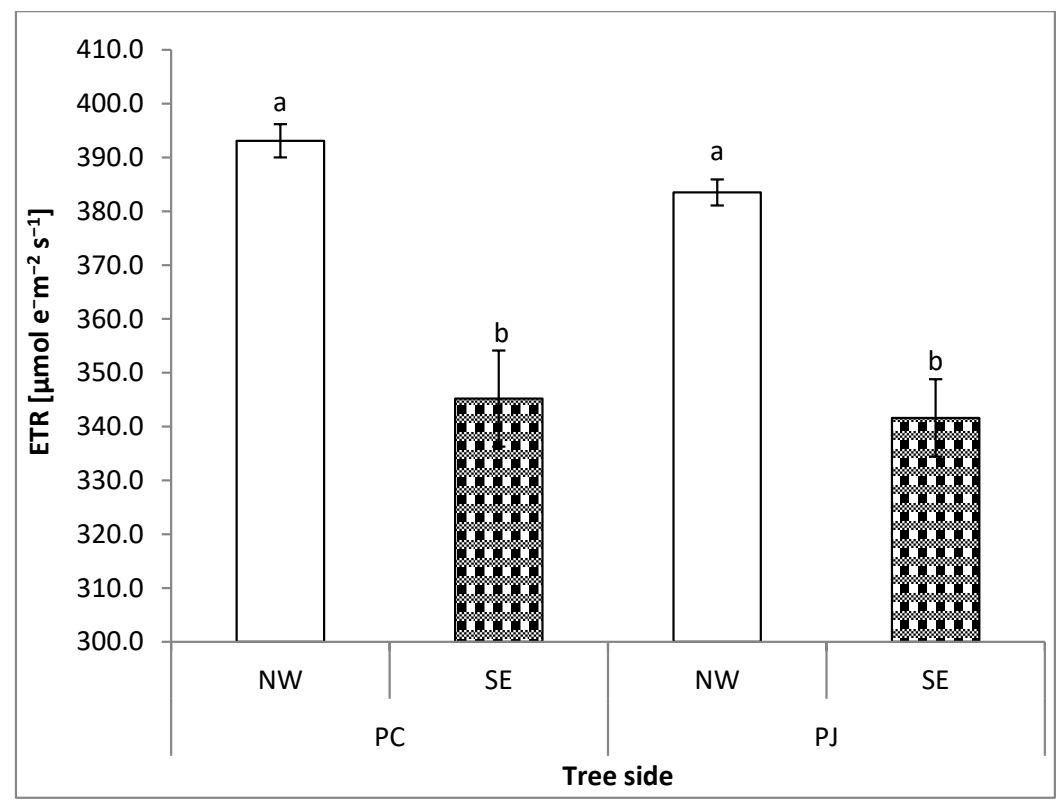

Figure 3. Changes in electron transport rate (ETR) $\left[\mu \mathrm{mol} \mathrm{e}^{-} \mathrm{m}^{-2} \mathrm{~s}^{-1}\right]$ in Prosopis juliflora and Prosopis cineraria leaves from east and west canopy directions. Each bar in a graph represents the mean $( \pm$ S.E. $)$ of three replicates. Means with the same letters within a species indicate insignificant difference between the two canopy positions at $p>0.05$ according to Duncan Multiple range test.

\subsection{Impact of Canopy Position on $q P, N P Q$ and Thermal Energy Dissipation Attributes}

The effect of canopy position (SE and NW) on several chlorophyll fluorescence traits (qP; NPQ) and heat energy dissipation $(1-\mathrm{qP}) / \mathrm{NPQ}$ were significant $(p<0.05)$. In both P. juliflora and P. cineraria, there was significant inhibition in the fluorescence quenching coefficient (qP) on SE as compared to NW canopy position (Figure 4a). Non-photochemical fluorescence quenching (NPQ) was significantly reduced on NW canopy position in P. juliflora than SE. However, NPQ decreased by $50 \%$ in P. cineraria on the SE canopy position than NW (Figure 4b).

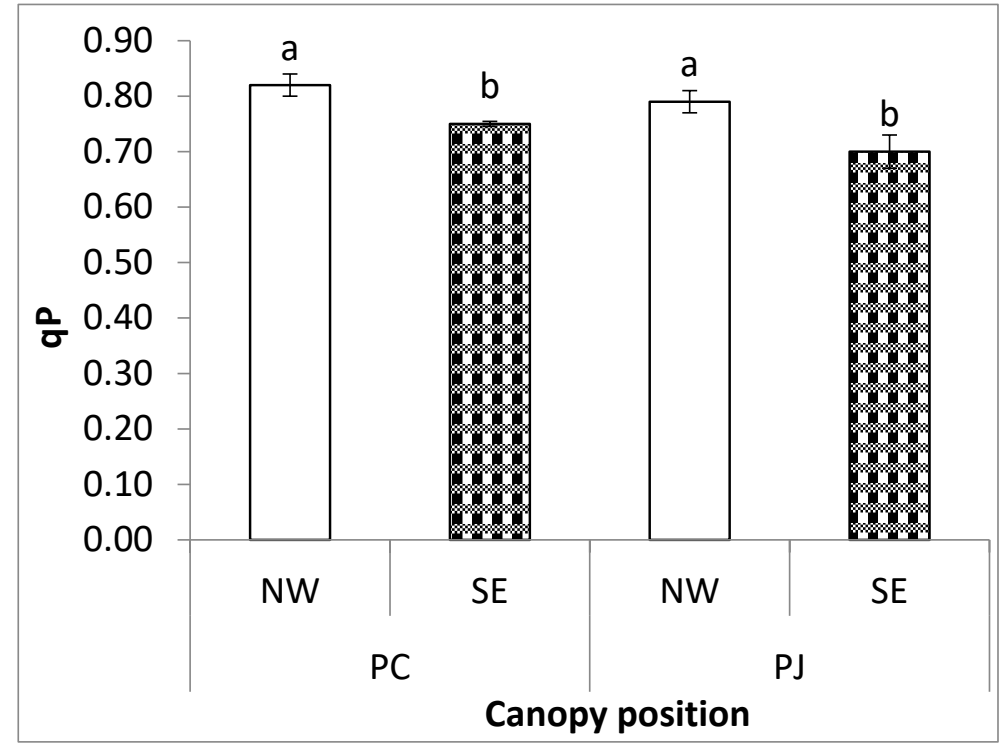

(a)

Figure 4. Cont. 


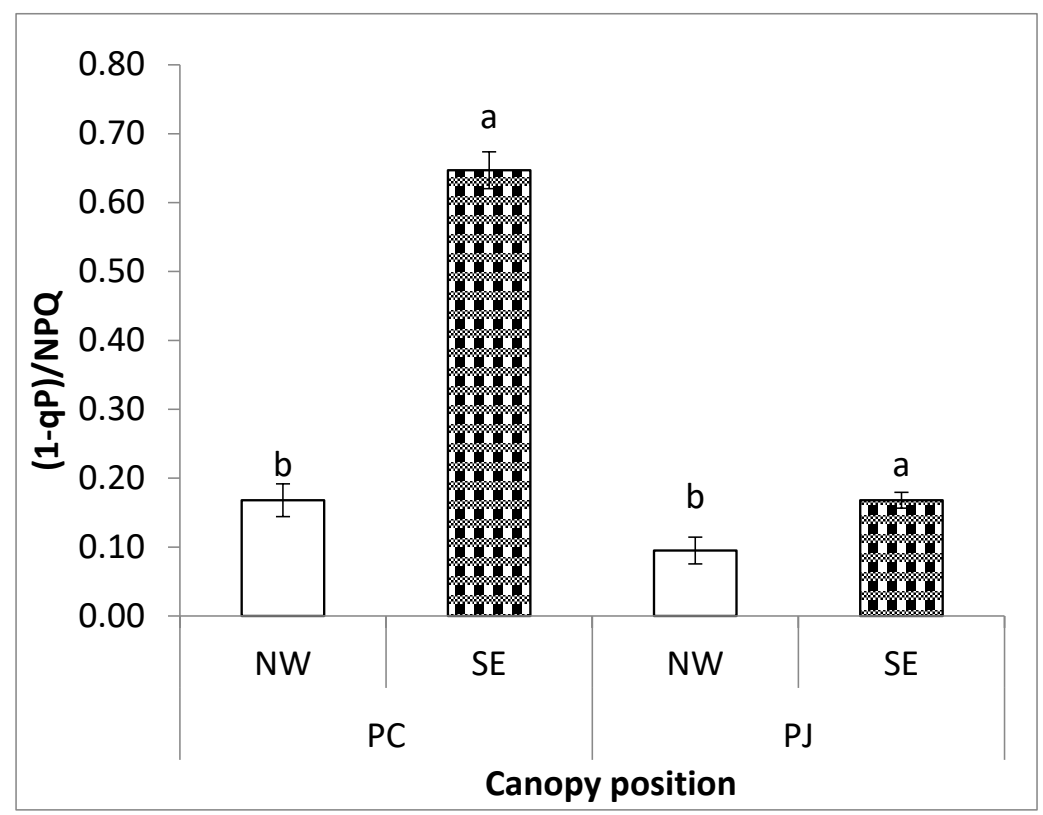

(b)

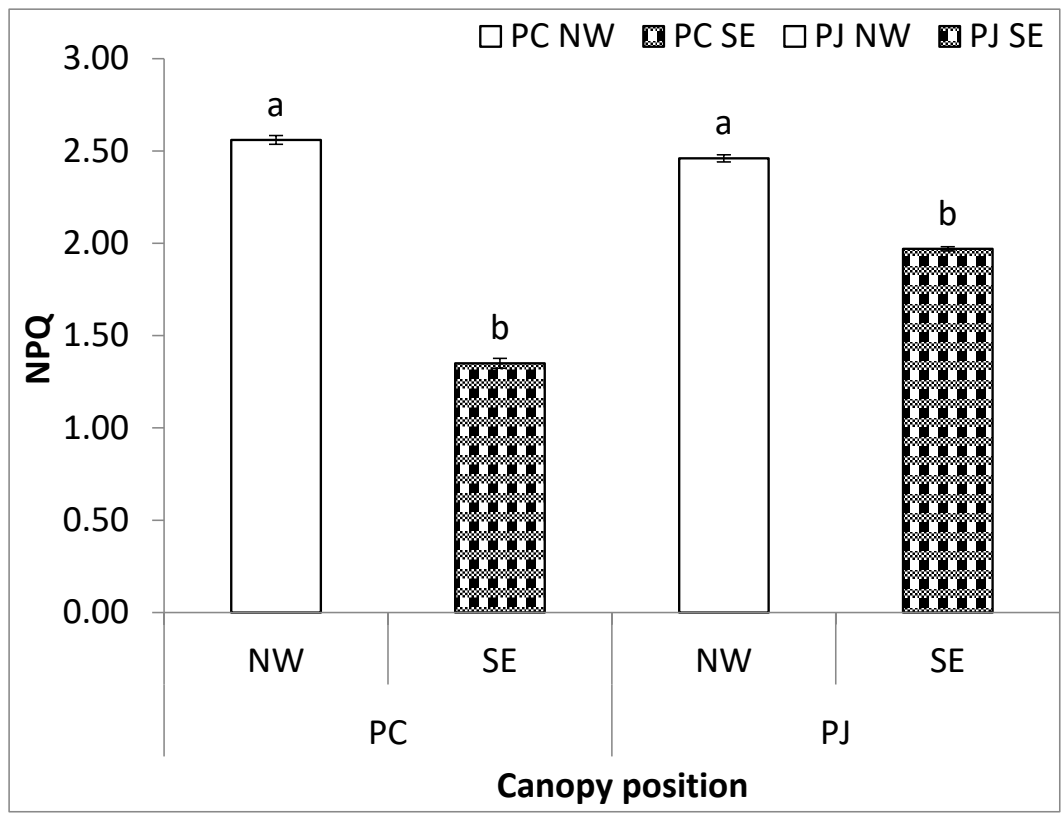

(c)

Figure 4. Changes in fluorescence quenching coefficients (a) $\mathrm{qP},(\mathbf{b})$ non-photochemical fluorescence quenching (NPQ), and (c) heat energy dissipation (1-qP)/NPQ in Prosopis juliflora and Prosopis cineraria leaves from different canopy position (south east, SE; north west, NW). Every column in each bar represents the mean $( \pm$ S.E. $)$ of the three replicates. Means with the same letters with a species indicates insignificant differences between the two canopy positions at $p>0.05$ according to Duncan Multiple range test.

There was significant difference in heat energy dissipation $(1-\mathrm{qP}) / \mathrm{NPQ}$ between $P$. juliflora and P. cineraria on both canopy positions. On the SE canopy position of P. cineraria, the heat energy dissipation $(1-\mathrm{qP}) / \mathrm{NPQ}$, was increased by $60.09 \%(p>0.05)$ as compared to NW, respectively, (Figure 4). This indicates a photoprotective mechanism of P. cineraria on the SE canopy positions during the summer month of May. 


\subsection{Effects of Canopy Position (NW and SE) on Leaf Water Content and Leaf Biomass of P. juliflora and P. cineraria}

Plant growth was measured by different growth traits including leaf fresh weight (LFW), leaf dry weight (LDW), leaf dry/fresh weight ratio (LD:LF ratio), and leaf relative water contents (WC). The LFW, LDW, and LD:LF ratio were significantly higher in P. juliflora than P. cineraria. However, canopy positions (NW or SE) did not show any impact on any of these parameters (Table 3). The effects of canopy position (NW and SE) on leaf water content of P. juliflora and P. cineraria were also non-significant $(p<0.001)$, and interaction between canopy position and WC in both invasive and native Prosopis species was also non-significant (Table 3).

Table 3. Effect of canopy position of Prosopis juliflora and Prosopis cineraria on the plant biomass traits (leaf fresh weight (g) LFW; leaf dry weight (g) LDW; leaf dry/fresh weight ratio, LD:FW; and water contents (WC).

\begin{tabular}{cccccc}
\hline & Tree Side & LFW & LDW & LD:FW & WC \\
\hline & South East & $5 \pm 1.04 \mathrm{a}$ & $2.4 \pm 0.1 \mathrm{a}$ & $0.48 \pm 0.05 \mathrm{a}$ & $1.06 \pm 0.8 \mathrm{a}$ \\
P. cineraria & North West & $5.3 \pm 1.8 \mathrm{a}$ & $2.4 \pm 0.00 \mathrm{a}$ & $0.45 \pm 0.01 \mathrm{a}$ & $1.13 \pm 0.73 \mathrm{a}$ \\
P. juliflora & South East & $8 \pm 1.00 \mathrm{a}$ & $4.6 \pm 0.02 \mathrm{a}$ & $0.57 \pm 0.02 \mathrm{a}$ & $1.31 \pm 0.3 \mathrm{a}$ \\
& North West & $7 \pm 0.98 \mathrm{a}$ & $4.1 \pm 0.03 \mathrm{a}$ & $0.58 \pm 0.02 \mathrm{a}$ & $1.21 \pm 0.5 \mathrm{a}$ \\
\hline
\end{tabular}

Means with the same letter are not significantly different from each other $(p>0.05$; ANOVA followed by Duncan multiple range test). Error lines represent means \pm S.E. of 3 replicates.

\subsection{Effects of Canopy Position (NW and SE) on Carbon Gain and Nitrogen Partitioning}

Leaf carbon and nitrogen contents were significantly higher in P. juliflora as compared to P. cineraria, particularly on the SE canopy position (Table 4). Meanwhile, more prominent result was obtained in nitrogen content that was 3 -fold higher in P. juliflora as compared to P. cineraria.

Table 4. Carbon and nitrogen contents and $\mathrm{C} / \mathrm{N}$ ratio in leaves of Prosopis juliflora (PJ), and Prosopis cineraria (PC) at two canopy positions (south east, SE; north west, NW).

\begin{tabular}{ccccccc}
\hline & \multicolumn{2}{c}{ Carbon \% } & \multicolumn{2}{c}{ Nitrogen \% } & \multicolumn{2}{c}{ C/N Ratios } \\
\hline Prosopis spp. & North West & South East & North West & South East & North West & South East \\
\hline PC & $40.8 \pm 0.11 \mathrm{bB}$ & $43.1 \pm 0.15 \mathrm{aB}$ & $1.5 \pm 0.01 \mathrm{aB}$ & $1.5 \pm 0.02 \mathrm{aB}$ & $27.2 \pm 0.15 \mathrm{bA}$ & $28.7 \pm 0.14 \mathrm{aA}$ \\
PJ & $45.3 \pm 0.13 \mathrm{bA}$ & $46.2 \pm 0.27 \mathrm{aA}$ & $4.35 \pm 0.03 \mathrm{aA}$ & $3.7 \pm 0.08 \mathrm{bA}$ & $10.41 \pm 0.10 \mathrm{bB}$ & $12.9 \pm 0.12 \mathrm{aB}$ \\
\hline
\end{tabular}

Means with the same letter (small or capital) are not significantly different from each other $(p>0.05$; ANOVA followed by Duncan multiple range test). Error lines represent means \pm S.E. of 3 replicates.

The effect of canopy position (southeast and northwest) on different elements ( $\mathrm{K}, \mathrm{P}, \mathrm{S}, \mathrm{Mg}^{2+}, \mathrm{Fe}^{2+}$, $\mathrm{Ca}^{2+}$, and $\mathrm{Zn}^{2+}$ ) were significant $(p<0.01$ and 0.05 ; Table 2). The impact of interaction between Prosopis species (P. cineraria and P. juliflora) and canopy position (southeast and northwest) on different elements $\left(\mathrm{K}, \mathrm{S}, \mathrm{Fe}^{2+}, \mathrm{Ca}^{2+}\right.$, and $\left.\mathrm{Zn}^{2+}\right)$ were significant $(p<0.01$ and 0.05$)$.

Different elements such as $\mathrm{K}, \mathrm{P}, \mathrm{S}$, and $\mathrm{Cl}$ attained significantly higher values in the $P$. juliflora leaves at both canopy positions as compared to P. cineraria (Table 5). There was significantly higher $\mathrm{Mg}^{2+}$ content in leaves of $P$. cineraria from NW as compared to SE canopy position (Figure 5). In P. juliflora, $\mathrm{Fe}^{2+}$ content decreased drastically in leaves exposure to SE canopy side than NW side. Maximum $\mathrm{Fe}^{2+}$ content was noted in leaves from NW canopy position of $P$. cineraria. Furthermore, $\mathrm{Fe}^{2+}$ contents were 2 -fold in P. cineraria leaves than in that of P. juliflora leaves (Figure 5). The $\mathrm{Ca}^{2+}$ content in P. cineraria leaves were higher from $P$. juliflora while $\mathrm{Ca}^{2+}$ content was unaffected due to canopy position in both plant species. The $\mathrm{Zn}^{2+}$ content in P. cineraria was higher in leaves exposure to NW canopy side than SE side. There $\mathrm{Zn}^{2+}$ content in P. juliflora leaves remain unaltered due to canopy position (Figure 5). 
Table 5. Different elemental concentrations in leaves of Prosopis juliflora (PJ) and Prosopis cineraria (PC) at different canopy position (south east and north west).

\begin{tabular}{|c|c|c|c|c|c|c|c|c|}
\hline Species & $\mathbf{K}$ & & $\mathbf{P}$ & & $\mathrm{S}$ & & $\mathrm{Cl}$ & \\
\hline & North West & South East & North West & South East & North West & South East & North West & South East \\
\hline PJ & $16.76 \pm 1$ & & $1.73 \pm 0$. & & $9.46 \pm 0.10 \mathrm{bA}$ & 10.48 & $8.36 \pm 0.26 \mathrm{aA}$ & $.31 \mathrm{bB}$ \\
\hline PC & $6.97 \pm 0.72 \mathrm{aB}$ & $5.15 \pm 0.32 \mathrm{bB}$ & $0.974 \pm 0.12 \mathrm{aB}$ & $0.86 \pm 0.06 \mathrm{aB}$ & $8.06 \pm 0.28 \mathrm{aB}$ & $8.59 \pm 0.33 \mathrm{aB}$ & $4.88 \pm 0.31 \mathrm{aB}$ & $6.059 \pm 0.49 \mathrm{aA}$ \\
\hline
\end{tabular}

Means with the same letter (small or capital) are not significantly different from each other $(p>0.05$; ANOVA

followed by Duncan multiple range test). Error lines represent means \pm S.E. of 3 replicates.
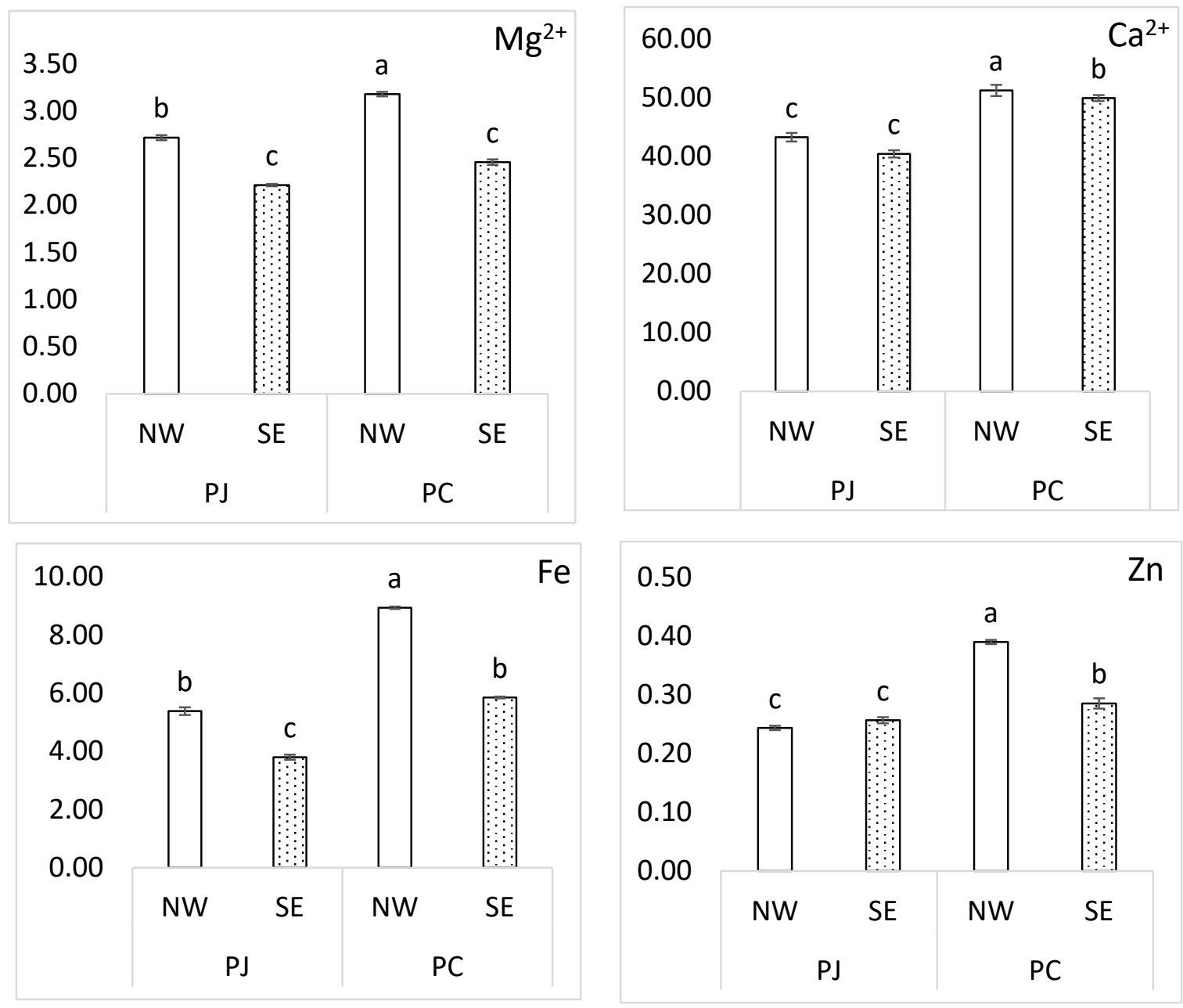

Figure 5. Magnesium (Mg), calcium (Ca), iron (Fe), and zinc ( $\mathrm{Zn})$ contents (dry weight basis) of leaves of Prosopis juliflora (PJ) and Prosopis cineraria (PC) from different canopy positions (south east, SE; north west, NW). Every column in each bar represents the mean ( \pm S.E.) of the three replicates. Means with the same letters with a species indicates insignificant differences between the two canopy positions at $p$ $>0.05$ according to Duncan Multiple range test.

\section{Discussion}

Difference in light interception and canopy position impact on Photosystem II (PSII) photochemistry, acclimation effects and thermal energy dissipation kinetics were analyzed in invasive $P$. juliflora and native $P$. cineraria in a natural habitat of hyper-arid climate of UAE using chlorophyll fluorescence attributes. Previously, some authors evaluated photosynthetic responses and respiration traits of the invasive P. juliflora $[26,34,35,46]$. However, in this study, we evaluated the dynamic response of light environment in terms of canopy positions (SE and NW), on leaf carbon gain, nitrogen partitioning, leaf ion homeostasis, photosynthetic efficiency, photo-protection through 
excess thermal energy dissipation, and physiological adaptation of Prosopis congeners under UAE hyper-arid environment.

The maximum efficiency of photosystem PSII $\left(\mathrm{F}_{\mathrm{v}} / \mathrm{F}_{\mathrm{m}}\right)$, in both P. juliflora and P. cineraria leaves, was higher at NW as compared to it at SE canopy position. This indicates that leaves at SE canopy position, were exposed to stronger light intensities and high temperature that might have resulted in such reduction in the $\mathrm{F}_{\mathrm{v}} / \mathrm{F}_{\mathrm{m}}$ ratio. In hyper-arid climates, high temperature and heat waves cause stomata closure that cause significant inhibition of photosynthesis due to limited $\mathrm{CO}_{2}$ supply, carboxylation rates, and decline in RuBisCO functionality [47-49]. Similar results were reported by [50], where they showed that plant growth and leaf physiological functions were significantly affected under temperature change scenario. In another study, it has been found that PSII photosynthetic efficiency and transpiration was greatly reduced under drought stress in Prosopis chilensis [46]. In the present study, we found a co-relation in the reductions of photosynthesis and $\mathrm{Mg}$ contents in P. cineraria. Inhibition of photosystem II photochemistry may also the consequences of individual or synergistic responses of high temperature, heat stress, phytotoxicity of allelochemicals released into the environment, unfolding of proteins, loss of manganese from the oxygen-evolving complex, chlorophyll pigments reduction, and magnesium deficiency [10,51-55]. Several studies have reported conflicting results about physiological attributes, such as photosynthesis and respiration, among invasive and native species [56]. However, our results demonstrated that the invasive P. juliflora maintain a slightly lower, but stable photosynthetic efficiency $\left(\mathrm{F}_{\mathrm{v}} / \mathrm{F}_{\mathrm{m}}\right)$, than the native P. cineraria under the hyper-arid environment of UAE. These results are consistent with those reported in other studies, which indicated that an invasive plant species does not need to have higher $F_{v} / F_{m}$ to overtop its native competitor growing in the same niche. Conversely, higher photosynthetic efficiency and gas exchange attributes have been reported in invasive plants, as compared with native species $[57,58]$. There was insignificant difference observed in stomatal conductance, leaf gas exchange traits and photosynthesis among the invasive Berberis thunbergii DC. and the native Kalmia latifolia L. and Vaccinium corymbosum L. [59]. This indicates that photosynthesis, as an individual trait, could not be held responsible to drive invasive success of $P$. juliflora and there might be other factors that contribute in its range expansion, invasion, and stand establishment.

The $\Phi P S I I$ values were greater in both $P$. juliflora and P. cineraria on the NW as compared to SE canopy position (Figure 2). Such reduction in $\Phi P S I I$ could be coincided with a decrease in the efficiency of excitation energy trapping of PSII reaction centers in the SE side. Moreover, inhibition in SPSII was more prominent in P. juliflora than P. cineraria. It has been well documented that $\Phi P S I I$ is reduced under water limited conditions. On the SE side, due to excess sunlight, high temperature increased transpiration, which might cause a stress that led to decrease in $\Phi P S I I$ values on the SE canopy position. Other researchers also have reported that water deficiency causes a significant reduction in excitation energy capture of open PSII reaction centers [60].

The physiological and biochemical characterization of NPQ has been described by several authors in details in several model plants [61-64]. In our study, NPQ values were significantly higher on NW canopy positions with a reduction on SE canopy position in both P. juliflora and P. cineraria, but this reduction in NPQ values were more prominent in the $P$. juliflora, showing that it is more adapted to local climatic conditions and has the capacity to dissipate excess energy as heat, which otherwise might disturb the photosynthetic machinery. According to a recent study conducted by [65], NPQ demonstrate a passive outlet for excess heat energy dissipation and thus helps in reducing pressure on the PSII reaction centers through protecting from excess heat energy damage. Thus, NPQ also improve the photosynthetic capacity and PSII photochemistry of plants under stress.

Several authors have reported the dissipation of any excess light energy in different tree species, such as Pinus contorta or Pinus ponderosa $[61,66,67]$ and the Eurasian Scots pine (Pinus sylvestris) $[68,69]$. However, less attention was given to plant species especially shrubs and trees from tropical, sub-tropical and hyper-arid climatic regions. To the best of our knowledge, this is the first study that highlights and compares the importance of photo-protection via thermal energy dissipation 
among the invasive $P$. juliflora and the native $P$. cineraria under the hyper-arid UAE climate. On the SE canopy position, the leaves of $P$. cineraria initiated an NPQ-dependent energy dissipation mechanism to improve the excessive summer heat tolerance and providing a protective mechanism to PSII. This indicates that excessive light, heat, and high temperature (mostly on SE canopy side), might inhibit the NPQ-dependent energy dissipation mechanism. When the summer heat increased on the SE canopy position, the excess excitation energy $(1-\mathrm{qP}) / \mathrm{NPQ}$ also increased abruptly; thus, resulting in a significant increase in NPQ-dependent energy dissipation mechanism. This was also one of the important reasons for the increase of photoinhibition in leaves of $P$. juliflora and the native P. cineraria on SE canopy side under the hyper-arid desert climate of the UAE. In this study, P. cineraria exhibited higher values of " $(1-\mathrm{qP}) / \mathrm{NPQ}^{\prime}$ c compared to $P$. juliflora, suggesting that native species might have greater potential to dissipate excess light energy to avoid photo-oxidative damage) at the canopy position that receive higher light intensities, as compared to invasive plants. It has been shown that the foliage of $P$. cineraria dissipated up to $40 \%$ of absorbed excess light that might be harmful to photosynthetic apparatus [70]. Other studies have also reported that thermal energy dissipation can reach to $92 \%$ of the total absorbed sun light/radiation [71]. Under abiotic stress conditions, plants have abilities to make adjustments in the photosynthetic apparatus and attributes, so that they can handle and tolerate the stress conditions and relieve the unfavorable influences on the photosynthetic apparatus. Different plants have developed different strategies to cope with adverse impact of PSII excitation due to excess light, which include the dissipation of excess light energy [10,63]. Some plants can make adjustment in the electron transport rate $\left(\mu \mathrm{mol} \mathrm{e}^{-} \mathrm{m}^{-2} \mathrm{~s}^{-1}\right)$ in the light harvesting complex (LHC) and within the PSII reaction centers to tolerate the excess light [72]. Furthermore, plants have several other photoprotection mechanisms that might help to protect them from excess heat damage and to avoid ROS production and involve xanthophyll cycle depend light energy dissipation that can protect antenna complex from excitation energy [73-75]. Furthermore, our study also highlights that photoprotection mechanism of the native $P$. cineraria through light energy dissipation is fundamentally more advanced than that of P. juliflora; the excess light energy absorbed by chlorophyll can be safely dissipated as heat to avoid reactive oxygen species generation. It is also advocated that dissipation of excess light is a complicated phenomenon and further study is required to summarize the diversity and evolution of photoprotective process in ecological and genetic contexts.

The photosynthetic efficiency in the light adapted state $\left(\mathrm{F}_{\mathrm{v}^{\prime}} / \mathrm{F}_{\mathrm{m}^{\prime}}\right)$ was significantly lower in $P$. cineraria on the SE, as compared to the NW canopy position. Such reduction in $\mathrm{F}_{\mathrm{v}^{\prime}} / \mathrm{F}_{\mathrm{m}^{\prime}}$ values can directly disturb the process of carbon assimilation [76], stomatal closure [77], or interference in the RuBisCO pathway. In this study, we also observed significantly lower $\mathrm{C}$ and $\mathrm{N}$ concentrations in the native $P$. cineraria as compared to invasive $P$. juliflora. This result indicates that canopy position and genetic diversity (i.e., species type) can significantly impacts the photosynthetic efficiency, quantum yield, and photon energy dissipation (Figure 4). Meanwhile, this study also expands our understanding about leaf absorbed light energy and its partitioning into three competing process: $\Phi$ PSII, NPQ, and " $P$ ". It is worth noting that $P$. cineraria increased $\Phi$ PSII and NPQ at the expenses of " $P$ " at both NW and SE canopy positions (Figures 2 and 4). Higher amounts of leaf absorbed light energy translocated to $\Phi$ PSI can contribute to an increase in growth under optimal light conditions. P. cineraria also increased NPQ and $\Phi P S I I$ in SE canopy position (high light intensity) compared with NW canopy position (lower light intensity) (Figure 2). The present results are in agreement with those reported by $[32,56,78]$. In contrast, [5], documented that energy dissipation of excess light did not depend neither species nor light intensities.

The carbon and nitrogen are vital elements for normal plant growth, photosynthesis, and development, and are an important indicator for $\mathrm{C}$ and $\mathrm{N}$ metabolism [79]. In the present study, the $\mathrm{C}$ and $\mathrm{N}$ contents from different canopy positions were obviously higher in the leaves of $P$. juliflora than in those of P. cineraria, indicating the better capacity of the former to maintain $\mathrm{C}$ and $\mathrm{N}$ metabolism than the latter in the hyper-arid marginal soil environment. Similar to many other physiological processes, $\mathrm{N}$ is a vital component of photosynthesis, chloroplast, and $\mathrm{RuBisCO}$ 
enzymes [80,81]. For a higher rate of photosynthesis, a significantly higher level of $\mathrm{N}$ is required [82,83]. In our study, high leaf nitrogen contents in the invasive P. juliflora might help this exotic plant to maintain a lower but stable photosynthesis in the new introduced range. In $P$. cineraria, higher light intensities on the SE canopy position might be responsible for increased root respiration that ultimately causes reduction in leaf $\mathrm{N}$. Other authors also reported that interfering in the RuBisCO function will also lead to leaf $\mathrm{N}$ reduction [84]. The $\mathrm{K}$ and $\mathrm{P}^{2+}$ content in $P$. juliflora leaves elevated progressively on both canopy sides as compared to P. cineraria. The plant nutrient status indicates significant changes in nutrient acquisition of the plant during a particular growth period (vegetative, flowering, and reproductive stages). This also helps to explain the physiological responses of the plant in respect of photosynthesis, hormones transport, and protein synthesis.

\section{Conclusions}

We conclude that canopy position (NW and SE) has significant impact on photosynthetic attributes and thermal energy dissipation among the two Prosopis species. Native P. cineraria trees showed higher maximum PSII efficiency $\left(\mathrm{F}_{\mathrm{v}} / \mathrm{F}_{\mathrm{m}}\right)$ and capacity to dissipate excess light energy as heat. P. juliflora was sensitive in shade conditions, where thermal energy dissipation was lower than P. cineraria. Meanwhile, P. juliflora exposed to high sunlight levels on SE canopy position was able to avoid permanent damage to their photosynthetic apparatus by lowering PSII efficiency, but it remained in a stable state through adjustment of nutrient resources and carbon gain. The higher photosynthetic efficiency in P. cineraria on both canopy positions (NW and SE), suggests that the use of higher density of this species in the artificial forests of the hot arid deserts of the UAE for future afforestation programs. In addition, the higher dissipation of excess energy in P. cineraria leaves would be behind the success of this species in the artificial forest and natural habitats of the hot arid climate, where the summer temperature can shoot up to $50{ }^{\circ} \mathrm{C}$.

Author Contributions: M.I.H. conducted the experiment, collected data, and drafted the manuscript. A.E.-K. designed the experiment and followed upon data collection, helped in article draft, correction, and revision. F.M.t. helped in field experimental measurements, article revision, and reference corrections. A.E.-K. provided support through the statistical analysis, revised, and edited the final manuscript. All authors have read and agreed to the published version of the manuscript.

Funding: This research was supported by the Project (Program Code 150428) "Employing congeneric \& Biogeographic approaches to study Prosopis juliflora invasion at regional and global scale" funded by the Vice Chancellor for Research and Graduate Studies, University of Sharjah, UAE.

Acknowledgments: We thank Attiat Al Najjar with field and laboratory assistance.

Conflicts of Interest: Authors declare no potential conflict of interest.

\section{References}

1. Maxwell, K.; Johnson, G. Chlorophyll fluorescence-A practical guide. J. Exp. Bot. 2000, 51, 659-668. [CrossRef]

2. Baker, N.R.; Oxborough, K. Chlorophyll Fluorescence as a Probe of Photosynthetic Productivity. In Plant Cell Monographs; Springer Science and Business Media LLC: Berlin/Heidelberg, Germany, 2007; Volume 19, pp. 65-82.

3. Baker, N.R. Chlorophyll fluorescence: A probe of photosynthesis in vivo. Annu. Rev. Plant Biol. 2008, 59, 89-113. [CrossRef]

4. Ledford, H.K.; Niyogi, K.K. Singlet oxygen and photo-oxidative stress management in plants and algae. Plant Cell Environ. 2005, 28, 1037-1045. [CrossRef]

5. Demmig-Adams, B.; Adams, W.W. Xanthophyll cycle and light stress in nature: Uniform response to excess direct sunlight among higher plant species. Planta 1996, 198, 460-470. [CrossRef]

6. Demmig-Adams, B.; Iii, W.W.A.; Barker, D.H.; Logan, B.A.; Bowling, D.R.; Verhoeven, A.S. Using chlorophyll fluorescence to assess the fraction of absorbed light allocated to thermal dissipation of excess excitation. Physiol. Plant. 2008, 98, 253-264. [CrossRef] 
7. Demmig-Adams, B.; Ebbert, V.; Mellman, D.L.; Mueh, K.E.; Schaffer, L.; Funk, C.; Zaeter, C.R.; Admska, I.; Jansson, S.; Adam, W.W. Modulation of PsbS and flexible vs. sustained energy dissipation by light environment in different species. Physiol. Plant 2006, 127, 670-680. [CrossRef]

8. Munekage, Y.; Hashimoto, M.; Miyake, C.; Tomizawa, K.-I.; Endo, T.; Tasaka, M.; Shikanai, T. Cyclic electron flow around photosystem I is essential for photosynthesis. Nature 2004, 429, 579-582. [CrossRef] [PubMed]

9. Hussain, M.I.; Reigosa, M.J. A chlorophyll fluorescence analysis of photosynthetic efficiency, quantum yield and fractions of photon energy in PSII antennae of Lactuca sativa exposed to cinnamic acid. Plant Physiol. Biochem. 2011, 49, 1290-1298. [CrossRef]

10. Hussain, M.I.; Reigosa, M.J. Evaluation of photosynthetic performance and carbon isotope discrimination in perennial ryegrass (Lolium perenne L.) under allelochemicals stress. Ecotoxicology 2017, 26, 613-624. [CrossRef]

11. Durnford, D.; Price, J.A.; McKim, S.M.; Sarchfield, M.L. Light-harvesting complex gene expression is controlled by both transcriptional and post-transcriptional mechanisms during photoacclimation in Chlamydomonas reinhardtii. Physiol. Plant. 2003, 118, 193-205. [CrossRef]

12. Kanervo, E.; Lehto, K.; Ståhle, K.; Lehto, H.; Mäenpää, P. Characterization of growth and photosynthesis of Synechocystis sp. PCC 6803 cultures under reduced atmospheric pressures and enhanced $\mathrm{CO}_{2}$ levels. Int. J. Astrobiol. 2005, 4, 97-100. [CrossRef]

13. Evans, J.R.; Poorter, H. Photosynthetic acclimation of plants to growth irradiance: The relative importance of specific leaf area and nitrogen partitioning in maximizing carbon gain. Plant Cell Environ. 2001, 24, 755-767. [CrossRef]

14. Walters, R.G. Towards an understanding of photosynthetic acclimation. J. Exp. Bot. 2004, 56, $435-447$. [CrossRef] [PubMed]

15. Mazzanatti, T.; Calzavara, K.A.; Pimenta, J.A.; Oliveira, H.C.; Moreina-Caixeta, H.; Bianchini, E. Light acclimation in nursery: Morphoanatomy and ecophysiology of seedlings of three light-demanding neotropical tree species. Braz. J. Bot. 2016, 39, 19-28. [CrossRef]

16. Kalaji, H.M.; Goltsev, V.; Bosa, K.; Allakhverdiev, S.I.; Strasser, R.J. Experimental in vivo measurements of light emission in plants: A perspective dedicated to David Walker. Photosynth Res. 2012, 114, 69-96. [CrossRef]

17. Acheampong, M.A.; Pakshirajan, K.; Annachhatre, A.P.; Lens, P.N. Removal of Cu (II) by biosorption onto coconut shell in fixed-bed column systems. J. Ind. Eng. Chem. 2013, 19, 841-848. [CrossRef]

18. Shackleton, R.T.; Le Maitre, C.D.; Pasiecznik, M.N.; Richardson, M.D. Prosopis: A global assessment of the biogeography, benefits, impacts and management of one of the world's worst woody invasive plant taxa. J. Plant Sci. 2014, 6, 1-18. [CrossRef]

19. Burkart, A. A monograph of the genus Prosopis (Leguminosae subfam. Mimosoideae). Catalogue of the recognized species of Prosopis. J. Amrnold Arbor. 1976, 57, 450-452.

20. Pasiecznik, N.M.; Felker, P.; Harris, P.J.C.; Harsh, L.N.; Cruz, G.; Tewari, J.C.; Cadoret, K.; Maldonado, L.J. The Prosopis juliflora-Prosopis pallida Complex: A Monograph; HDRA: Coventry, UK, 2001; p. 172.

21. El-Keblawy, A.A.; Ksiksi, T.S. Artificial forests as conservation sites for the native flora of the UAE. For. Ecol. Manag. 2005, 213, 288-296. [CrossRef]

22. El-Keblawy, A. Greening Gulf Landscapes. In Environmental Politics in the Middle East; Oxford University Press (OUP): Oxford, UK, 2018; pp. 99-120.

23. El-Keblawy, A.; Bhatt, A.; Gairolla, S. Storage on maternal plants affects light and temperature requirements during germination in two small seeded halophytes in the Arabian deserts. Pak. J. Bot. 2015, 47, 1701-1708.

24. El-Keblawy, A.A.; Al-Rawai, A. Impacts of the invasive exotic Prosopis juliflora (Sw.) D.C. on the native flora and soils of the UAE. Plant Ecol. 2006, 190, 23-35. [CrossRef]

25. Dzikiti, S.; Schachtschneider, K.; Naiken, V.; Gush, M.B.; Moses, G.; Le Maitre, D.; Le Maitre, D.C. Water relations and the effects of clearing invasive Prosopis trees on groundwater in an arid environment in the Northern Cape, South Africa. J. Arid. Environ. 2013, 90, 103-113. [CrossRef]

26. Elfadl, M.; Luukkanen, O. Field studies on the ecological strategies of Prosopis juliflora in a dryland ecosystem. J. Arid. Environ. 2006, 66, 1-15. [CrossRef]

27. El-Keblawy, A.A.; Abdelfatah, M.A. Impacts of native and invasive exotic Prosopis congeners on soil properties and associated flora in the arid United Arab Emirates. J. Arid. Environ. 2014, 100, 1-8. [CrossRef] 
28. Van Kleunen, M.; Dawson, W.; Schlaepfer, D.R.; Jeschke, J.M.; Fischer, M. Are invaders different? A conceptual framework of comparative approaches for assessing determinants of invasiveness. Ecol. Lett. 2010, 13, 947-958. [CrossRef] [PubMed]

29. Callaway, R.M.; Pennings, S.C.; Richards, C.L. Phenotypic plasticity, and interactions among plants. Plant Ecol. 2003, 84, 1115-1128. [CrossRef]

30. Davidson, A.M.; Jennions, M.D.; Nicotra, A.B. Do invasive species show higher phenotypic plasticity than native species and, if so, is it adaptive? A meta-analysis. Ecol. Lett. 2011, 14, 419-431. [CrossRef] [PubMed]

31. Ghalambor, C.K.; McKay, J.K.; Carroll, S.P.; Reznick, D. Adaptive versus non-adaptive phenotypic plasticity and the potential for contemporary adaptation in new environments. Funct. Ecol. 2007, 21, $394-407$. [CrossRef]

32. Daehler, C.C. Performance comparisons of co-occurring native and alien invasive plants: Implications for conservation and restoration. Ann. Rev. Ecol. Evolut. 2003, 341, 183-211. [CrossRef]

33. Oguchi, M.; Kameya, T.; Yagi, S.; Urano, K. Product flow analysis of various consumer durables in Japan. Resour. Conserv. Recycl. 2008, 52, 463-480. [CrossRef]

34. Shirke, P.A.; Pathre, U. Diurnal and seasonal changes in photosynthesis and photosystem 2 photochemical efficiency in Prosopis juliflora leaves subjected to natural environmental stress. Photosynthetica 2003, 41, 83-89. [CrossRef]

35. Shirke, P.A. Influence of leaf-to-air vapour pressure deficit (VPD) on the biochemistry and physiology of photosynthesis in Prosopis juliflora. J. Exp. Bot. 2004, 55, 2111-2120. [CrossRef]

36. Slot, M.; Krause, G.H.; Krause, B.; Hernández, G.G.; Winter, K. Photosynthetic heat tolerance of shade and sun leaves of three tropical tree species. Photosynth. Res. 2018, 141, 119-130. [CrossRef]

37. Hussain, M.I.; El-Keblawy, A.A.; Tsombou, F.M. Leaf age, canopy position, and habitat affect the carbon isotope discrimination and water-use efficiency in three $\mathrm{C}_{3}$ leguminous prosopis species from a hyper-arid climate. Plants 2019, 8, 402. [CrossRef] [PubMed]

38. Genty, B.; Briantais, J.-M.; Baker, N.R. The relationship between the quantum yield of photosynthetic electron transport and quenching of chlorophyll fluorescence. Biochim. Biophys. Acta Gen. Subj. 1989, 990, 87-92. [CrossRef]

39. Schreiber, U.; Schliwa, W.; Bilger, U. Continuous recording of photochemical and non-photochemical chlorophyll fluorescence quenching with a new type of modulation fluorometer. Photosynth. Res. 1986, 10, 52-62. [CrossRef]

40. Hu, Y.; Sun, G.-Y.; Wang, X.-C. Induction characteristics and response of photosynthetic quantum conversion to changes in irradiance in mulberry plants. J. Plant Physiol. 2007, 164, 959-968. [CrossRef]

41. Zhang, H.; Li, X.; Chen, Y.-H.; Wang, Y.; Li, M.-B.; Yang, R.-Y.; Xu, N.; Sun, G.-Y. A study on the effects of salinity and $\mathrm{pH}$ on PSII function in mulberry seedling leaves under saline-alkali mixed stress. Trees 2020, 34, 693-706. [CrossRef]

42. Abbas, A.; Rubio-Casal, A.E.; De Cires, A.; Grewell, B.; Castillo, J.M. Differential tolerance of native and invasive tree seedlings from arid African deserts to drought and shade. S. Afr. J. Bot. 2019, 123, 228-240. [CrossRef]

43. Hussain, M.I.; Reigosa, M.J. Seedling growth, leaf water status and signature of stable carbon isotopes in $C_{3}$ perennials exposed to natural phytochemicals. Aust. J. Bot. 2012, 60, 676. [CrossRef]

44. Attaelmanan, A.G.; Kawam, M.A. Determining the elemental composition of Calotropis procera using X-ray Analytical Microscopy. X Ray Spectrom. 2012, 41, 284-287. [CrossRef]

45. Hussain, M.I.; El-Keblawy, A.A.; Elwakil, A.S. Aluminum influence on Calotropis procera seedling growth, nutrient accumulation, and electrochemical attributes. Flora Morphol. Distrib. Funct. Ecol. Plants 2018, 248, 34-42. [CrossRef]

46. Delatorre, J.; Pinto, M.; Cardemil, L. Effects of water stress and high temperature on photosynthetic rates of two species of Prosopis. J. Photochem. Photobiol. B Boil. 2008, 92, 67-76. [CrossRef] [PubMed]

47. Teskey, R.O.; Wertin, T.; Bauweraerts, I.; Ameye, M.; McGuire, M.A.; Steppe, K. Responses of tree species to heat waves and extreme heat events. Plant Cell Environ. 2014, 38, 1699-1712. [CrossRef] [PubMed]

48. Allakhverdiev, S.; Kreslavski, V.D.; Klimov, V.V.; Los, D.A.; Carpentier, R.; Mohanty, P. Heat stress: An overview of molecular responses in photosynthesis. Photosynth. Res. 2008, 98, 541-550. [CrossRef] [PubMed]

49. Takahashi, S.; Badger, M.R. Photoprotection in plants: A new light on photosystem II damage. Trends Plant Sci. 2011, 16, 53-60. [CrossRef] 
50. Morales, M.S.; Villalba, R.; Grau, H.R.; Villagra, P.E.; Boninsegna, J.A.; Ripalta, A.; Paolini, L. Potencialidad de Prosopis ferox Griseb (Leguminosae, subfamilia: Mimosoideae) para estudios dendrocronológicos en desiertos subtropicales de alta montaña. Rev. Chil. Hist. Nat. 2001, 74, 865-872. [CrossRef]

51. Schreiber, U.; Berry, J.A. Heat-induced changes of chlorophyll fluorescence in intact leaves correlated with damage of the photosynthetic apparatus. Planta 1977, 136, 233-238. [CrossRef]

52. Enami, I.; Kitamura, M.; Tomo, T.; Isokawa, Y.; Ohta, H.; Katoh, S. Is the primary cause of thermal inactivation of oxygen evolution in spinach PS II membranes release of the extrinsic $33 \mathrm{kDa}$ protein or of Mn? BBA Bioenerget. 1994, 1186, 52-58. [CrossRef]

53. Hussain, M.I.; González, L.; Souto, X.; Reigosa, M.J. Ecophysiological responses of three native herbs to phytotoxic potential of invasive Acacia melanoxylon R. Br. Agrofor. Syst. 2011, 83, 149-166. [CrossRef]

54. Hussain, M.I.; Reigosa, M.J. Allelochemical stress inhibits growth, leaf water relations, PSII photochemistry, non-photochemical fluorescence quenching, and heat energy dissipation in three $\mathrm{C}_{3}$ perennial species. J. Exp. Bot. 2011, 62, 4533-4545. [CrossRef] [PubMed]

55. Hussain, M.I.; Reigosa, M.J. Characterization of xanthophyll pigments, photosynthetic performance, photon energy dissipation, reactive oxygen species generation and carbon isotope discrimination during artemisinin-induced stress in Arabidopsis thaliana. PLoS ONE 2015, 10, e0114826. [CrossRef] [PubMed]

56. Funk, J.L. Differences in plasticity between invasive and native plants from a low resource environment. J. Ecol. 2008, 96, 1162-1173. [CrossRef]

57. Leishman, M.R.; Haslehurst, T.; Ares, A.; Baruch, Z. Leaf trait relationships of native and invasive plants: Community- and global-scale comparisons. New Phytol. 2007, 176, 635-643. [CrossRef]

58. McDowell, S.C.L. Photosynthetic characteristics of invasive and noninvasive species of Rubus (Rosaceae). Am. J. Bot. 2002, 89, 1431-1438. [CrossRef]

59. Boyd, J.N.; Xu, C.-Y.; Griffin, K.L. Cost-effectiveness of leaf energy and resource investment of invasive Berberis thunbergii and co-occurring native shrubs. Can. J. For. Res. 2009, 39, 2109-2118. [CrossRef]

60. Roháček, K.; Bartak, M. Technique of the Modulated Chlorophyll Fluorescence: Basic Concepts, Useful Parameters, and Some Applications. Photosynthetica 1999, 37, 339-363. [CrossRef]

61. Adams, W.W.; Demmig-Adams, B. Photoprotection in an ecological context: The remarkable complexity of thermal energy dissipation. New Phytol. 2006, 172, 11-21. [CrossRef]

62. Jahns, P.; Latowski, D.; Strzalka, K. Mechanism and regulation of the violaxanthin cycle: The role of antenna proteins and membrane lipids. Biochim. Biophys. Acta Bioenerg. 2009, 1787, 3-14. [CrossRef]

63. Jahns, P.; Holzwarth, A.R. The role of the xanthophyll cycle and of lutein in photoprotection of photosystem II. Biochim. Biophys. Acta Bioenerg. 2012, 1817, 182-193. [CrossRef]

64. Murchie, E.H.; Niyogi, K.K. Manipulation of photoprotection to improve plant photosynthesis. Plant Physiol. 2010, 155, 86-92. [CrossRef] [PubMed]

65. Da, Q.; Jin, H.; Li, M.; Feng, D.; Wang, H.-B.; Sun, T.; Wang, M.; Wang, J.; Liu, B. M-type thioredoxins are involved in the xanthophyll cycle and proton motive force to alter NPQ under low-light conditions in Arabidopsis. Plant Cell Rep. 2017, 37, 279-291. [CrossRef] [PubMed]

66. Zarter, C.R.; Adams, W.W.; Ebbert, V.; Cuthbertson, D.J.; Adamska, I.; Demmig-Adams, B. Winter down-regulation of intrinsic photosynthetic capacity coupled with up-regulation of Elip-like proteins and persistent energy dissipation in a subalpine forest. New Phytol. 2006, 172, 272-282. [CrossRef] [PubMed]

67. Zarter, C.R.; Demmig-Adams, B.; Ebbert, V.; Adamska, I.; Adams, W.W. Photosynthetic capacity, and light harvesting efficiency during the winter-to-spring transition in subalpine conifers. New Phytol. 2006, 172, 283-292. [CrossRef] [PubMed]

68. Sveshnikov, D.; Ensminger, I.; Ivanov, A.; Campbell, D.A.; Lloyd, J.; Funk, C.; Hüner, N.P.A.; Oquist, G. Excitation energy partitioning and quenching during cold acclimation in Scots pine. Tree Physiol. 2006, 26, 325-336. [CrossRef] [PubMed]

69. Porcar-Castell, A. A high-resolution portrait of the annual dynamics of photochemical and non-photochemical quenching in needles of Pinus sylvestris. Physiol. Plant. 2011, 143, 139-153. [CrossRef]

70. Hendrickson, L.; Furbank, R.T.; Chow, W.S. A simple alternative approach to assessing the fate of absorbed light energy using chlorophyll fluorescence. Photosynth. Res. 2004, 82, 73-81. [CrossRef]

71. Flexas, J.; Medrano, H. Drought-inhibition of photosynthesis in $\mathrm{C}_{3}$ plants: Stomatal and non-stomatal limitations revisited. Ann. Bot. 2002, 89, 183-189. [CrossRef] 
72. Derks, A.; Schaven, K.; Bruce, D. Diverse mechanisms for photoprotection in photosynthesis. Dynamic regulation of photosystem II excitation in response to rapid environmental change. Biochim. Biophys. Acta Bioenerg. 2015, 1847, 468-485. [CrossRef]

73. Li, Z.; Ahn, T.K.; Avenson, T.J.; Ballottari, M.; Cruz, J.A.; Kramer, D.M.; Bassi, R.; Fleming, G.R.; Keasling, J.D.; Niyogi, K.K. Lutein Accumulation in the Absence of Zeaxanthin Restores Nonphotochemical Quenching in the Arabidopsis thaliana npq1 Mutant [W][OA]. Plant Cell 2009, 21, 1798-1812. [CrossRef]

74. Muller, H.S.P.; Thorwirth, S.; Roth, D.A.; Winnewisser, G. The cologne database for molecular spectroscopy, CDMS. Astron. Astrophys. 2001, 370, 49-52. [CrossRef]

75. Pérez-Bueno, M.L.; Johnson, M.P.; Zia, A.; Ruban, A.V.; Horton, P.; Lett, F.E.B.S. Elevated $\Delta$ pH restores rapidly reversible photoprotective energy dissipation in Arabidopsis chloroplasts deficient in lutein and xanthophyll cycle activity. Planta 2008, 582, 1477-1482.

76. Bollig, C.; Feller, U. Impacts of drought stress on water relations and carbon assimilation in grassland species at different altitudes. Agric. Ecosyst. Environ. 2014, 188, 212-220. [CrossRef]

77. Bertolde, F.Z.; Almeida, A.-A.F.; Pirovani, C.P.; Gomes, F.P.; Ahnert, D.; Baligar, V.C.; Valle, R.R. Physiological and biochemical responses of Theobroma cacao L. genotypes to flooding. Photosynthetica 2012, 50, 447-457. [CrossRef]

78. Molina-Montenegro, M.A.; Carrasco-Urra, F.; Rodrigo, C.; Convey, P.; Valladaress, F.; Gianoli, E. Occurrence of the non-native annual bluegrass on the Antartic Mainland and its negative effects on native plants. Conserv. Biol. 2012, 26, 717-723. [CrossRef]

79. Wingler, A.; Purdy, S.; MacLean, J.A.; Pourtau, N. The role of sugars in integrating environmental signals during the regulation of leaf senescence. J. Exp. Bot. 2005, 57, 391-399. [CrossRef]

80. Makino, A.; Osmond, B. Effects of nitrogen nutrition on nitrogen partitioning between chloroplasts and mitochondria in pea and wheat. Plant Physiol. 1991, 96, 355-362. [CrossRef]

81. Theobald, J.C.; Mitchell, R.A.C.; Parry, M.A.J.; Lawlor, D.W. Estimating the Excess Investment in Ribulose-1,5-Bisphosphate Carboxylase/Oxygenase in Leaves of Spring Wheat Grown under Elevated $\mathrm{CO}_{2}$. Plant Physiol. 1998, 118, 945-955. [CrossRef]

82. Terashima, I.; Araya, T.; Miyazawa, S.-I.; Sone, K.; Yano, S. Construction and maintenance of the optimal photosynthetic systems of the leaf, herbaceous plant and tree: An eco-developmental treatise. Ann. Bot. 2004, 95, 507-519. [CrossRef]

83. Niinemets, Y.; Anten, N.P.R. Packing the Photosynthetic Machinery: From Leaf to Canopy; Springer Science and Business Media LLC: Berlin/Heidelberg, Germany, 2009; Volume 29, pp. 363-399.

84. Seneweera, S.; Makino, A.; Hirotsu, N.; Norton, R.; Suzuki, Y. New insight into photosynthetic acclimation to elevated $\mathrm{CO}_{2}$ : The role of leaf nitrogen and ribulose-1,5-bisphosphate carboxylase/oxygenase content in rice leaves. Environ. Exp. Bot. 2011, 71, 128-136. [CrossRef] 